
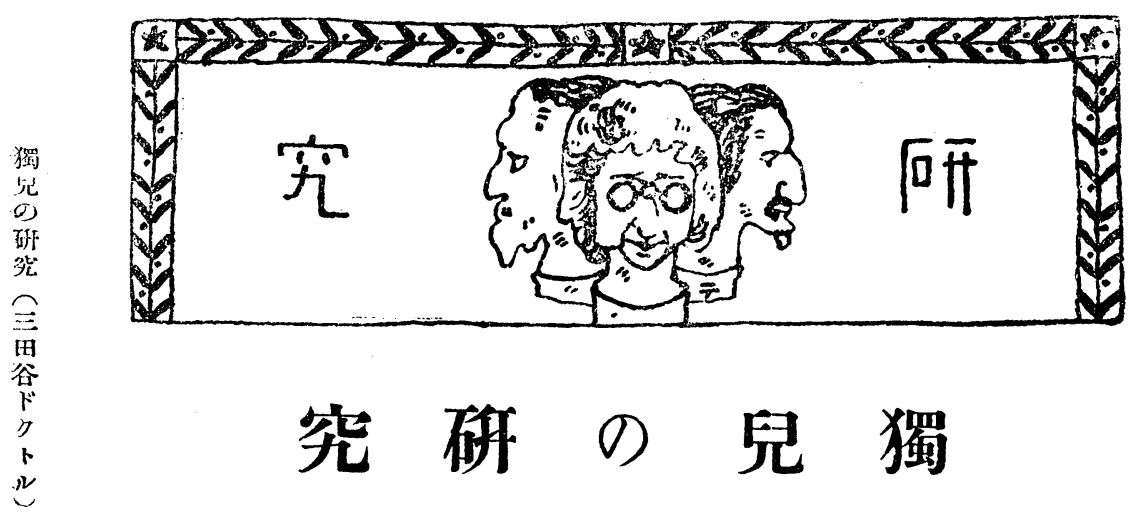

\title{
究研の兒 獨
}

啓谷田 三ルトクド

居きてを手兒蔳及の

る報居限がなのび兒こ

告る $る$ 行る狀獨童の

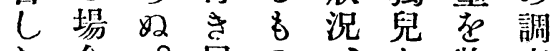

ね合。届の收查

るす從くは學自容以

当市主兄業做世主

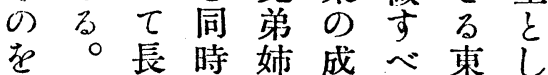

第
+
突
蛋
总

兒從長時姉成へ東し

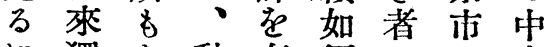

に獨市動有何に立產

、兒るるす存つ某階

凡の代する觀き尔級

研 引梠者察七學 0

左究にばに調、校家

第 の他愛比査身

如行のにしし體齐よ

き 一溺 $\tau$ 發學

條、面记家 U㕕年涌

四件显にた庭での學

(1) 沉は養にあ狀通せ

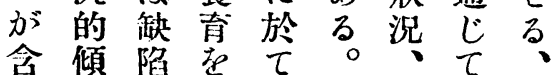

を向をせは一精、約

的有邓十體神獨八

$\tau$ 就 $し \varepsilon$ 分獨發兒百

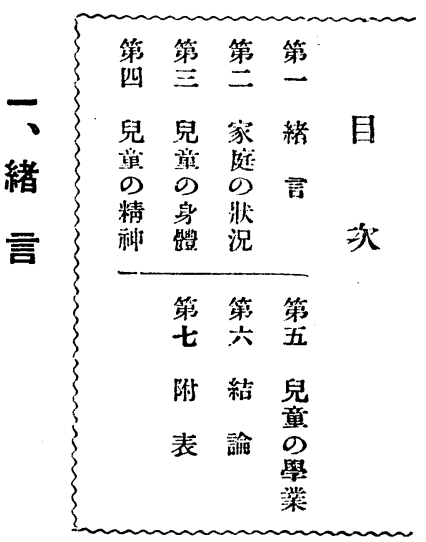




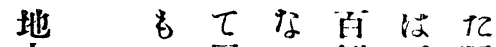

方フの居加例正獨 維

のリでりつ方上兒也

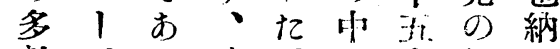

數ドつ殊。で人例の

のュたに殘普ではド

兒ン。其る通む百ク

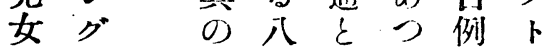

を氐中十見的でル

有は毕毕做。其》

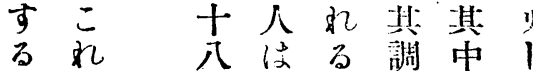

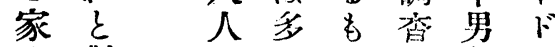

庭對少少成兒工

か照文种注績流ン

ら宩の經僅を四グ

、る 程怓卡見十 氏

前目度徵十弓活。

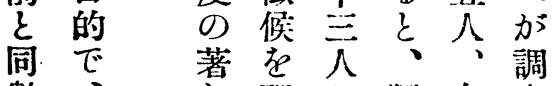

數: し琴し獨女查

百同いしか兒兒し

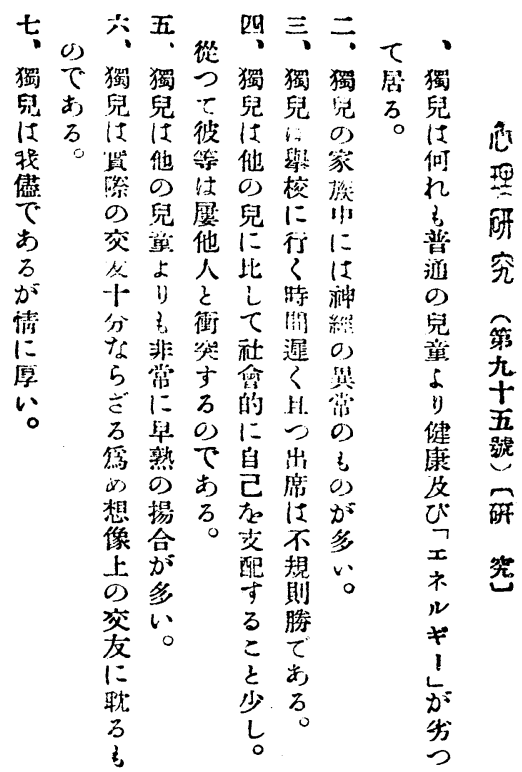

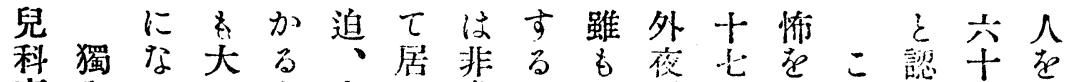

專兒るにと留る笛や縱間人認のめ范

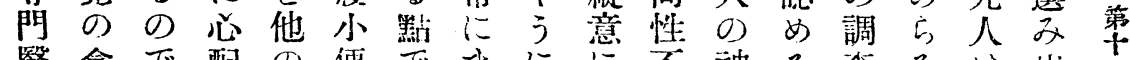

醫食で配の便で出に心不神る宜る心活兵

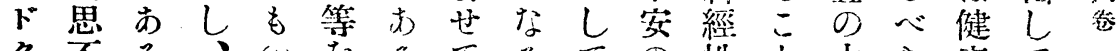

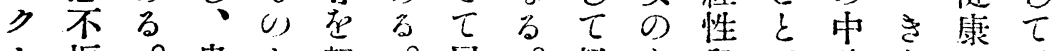

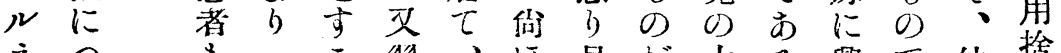

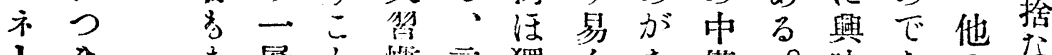

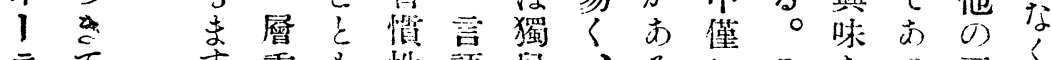

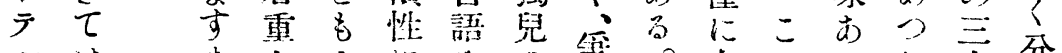

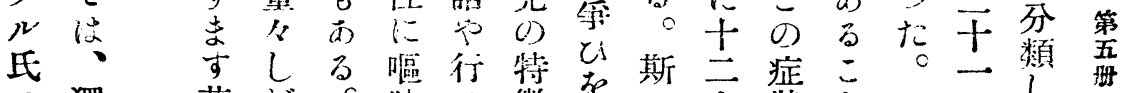

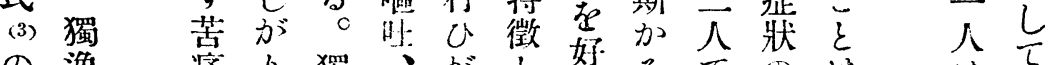

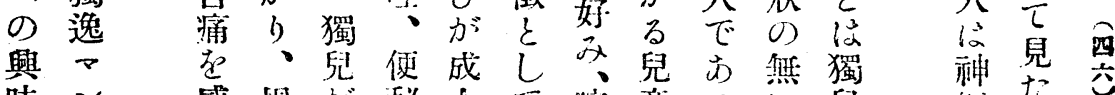

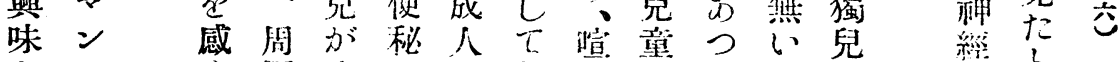

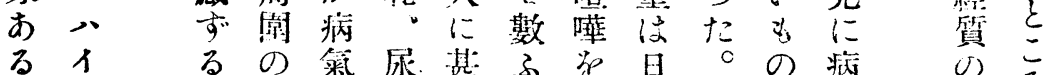

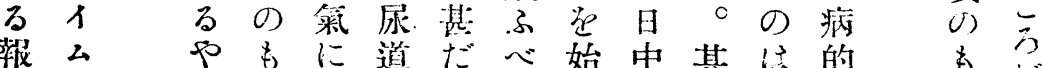

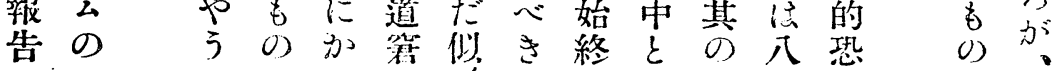


養れの十

女は中光本

切䎾は名研

獨事純養女

兒存粹子垔子

知 四三稚

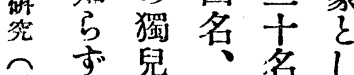

要に兒養名名

䀰矢は女數

張な四亏兒

兒が加事の

だ含と人

と兒まな員

思童礼つ品

つ自てた

$\tau$ 身 ○僅

るはる 而加

養。气に
獨心名了童

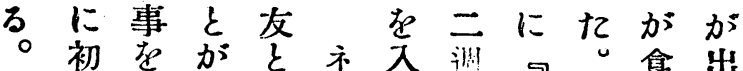

めす少し1 れ間气令出 てるいてテたのを不居 活こ、雨少處後焉振る

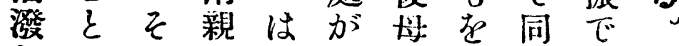
なにれやこ胃か幼氏市之 るなが年の病ら稚はるれ 食了幼長事は郝间—たは

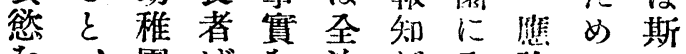

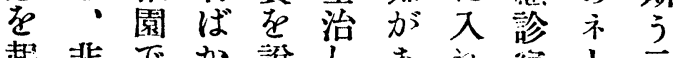
起非でか說しあ礼祭 I云

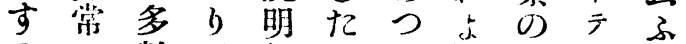
のに數でし で踰のはて言りを樂にけ

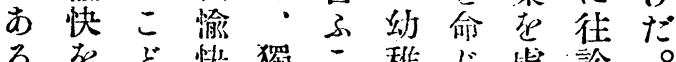
るを飞快獨こ稚に處訬。

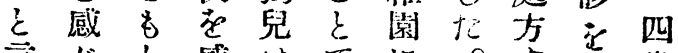
言じと威はでに。高依藏 つて其吉食あこ其る依の て长卓るそ心代賴獨 居茲食已の後bし兒

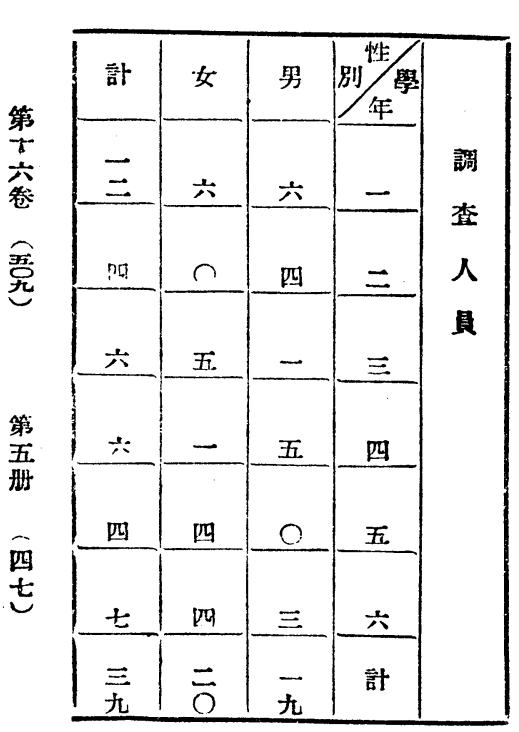

とこ併觀家しいく 次今 し察庭住の死純

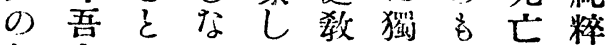
如人ながた育兒市しの

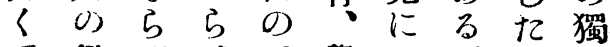
で行ば、で學つ。の兒 あつ幾若あ校き本での るた分しる呚て研・中 ○獨分此が莦、究今に 兒參の、のそは㧧 の考種調參の! 文か 性資の香考長か心 0 別料研人た所か面儿

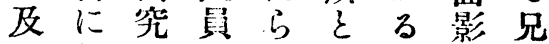
犾な尼缺標だ弟 學方諸極め陷準に加 年で所めんとに記 す

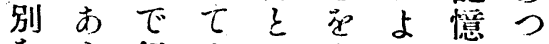
をら行少心發りした 擧う绐な目見ててが

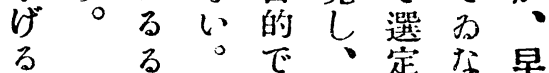


六と、筫四五者最三加正

人、職翻、、は年干養六家 商業ののの六末長五親年庭

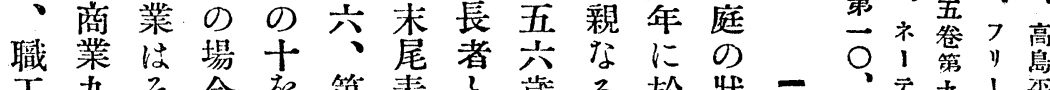

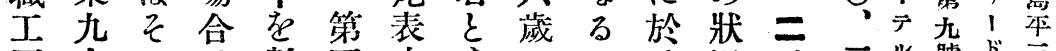

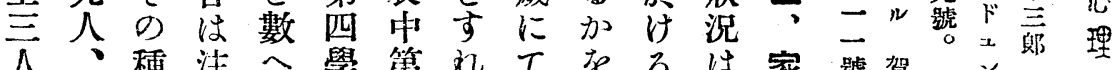

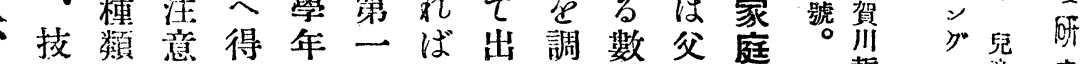
車術極卞了例學、產査へ母の娎三竞究 夫者めべの一年そしし年を狀抄田精

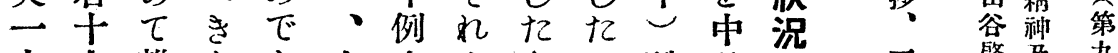

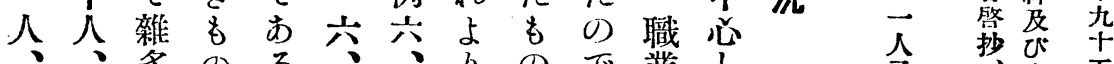

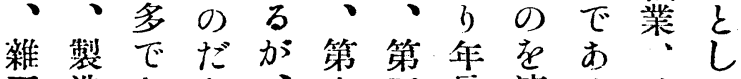

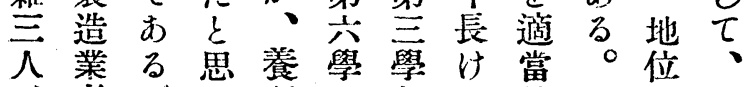

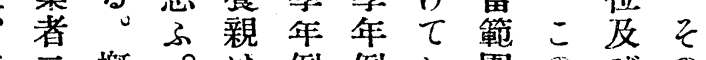

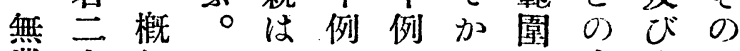

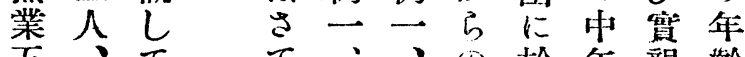

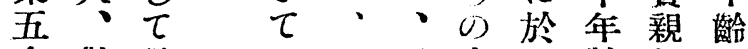
人勤言出三三出け龄な

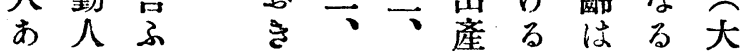

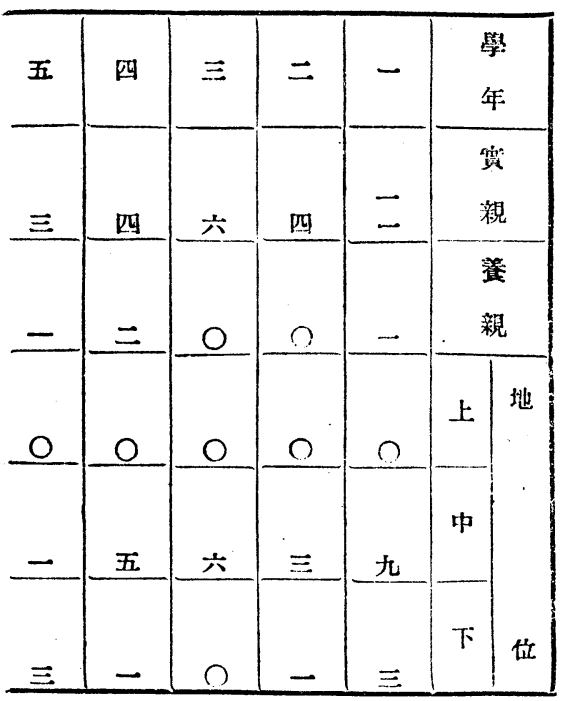

こるははでらすする と。兒下お制る。 に而童位る, 定当地 す ᄂ 總次 か し 0 位第 るて 數は、艺仙六 是三上圭上、そ综 等市位表中德 0 の九坛望闺吾 問人心示の、園 題のふす三信に は中順如階用於 必三序く級等け 要十に、に老る 五 に一な中區標政 制 㤫、隹、位分隻會 し養て がしと西 $\tau$ 親 る 最 $し$ し 以はる多調て地 下八。數查管位 还を文だし識走 心數 霬 、た龙 る人漞次の加味 


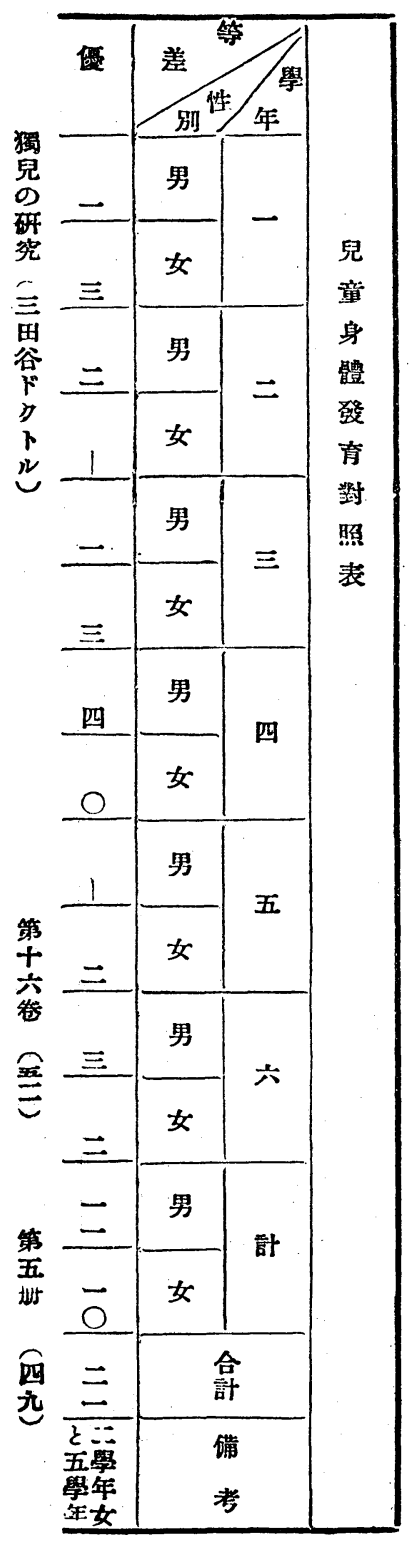

方尋査ち

法常し、兒

の小、每童

一學更學 の

揑校に年身

を兒之四體

加童を月は

へ發大に

肎正於身

表开心長

母 $\varepsilon$ 年 $\tau$

乳、對四检娟

に照月查重

$\tau し に$ せ

生 $\tau$ 檢 $L$ 笱

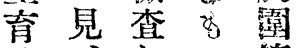

せ ( ᄂ O 等

しそたにの

加风口 各

-に東き項

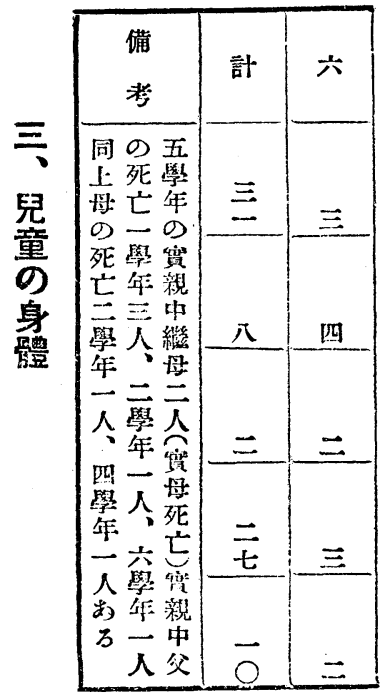

又生京てに

は充市調分

優男十較のそ三四間牛

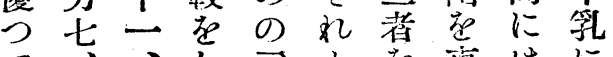

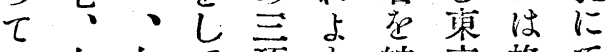

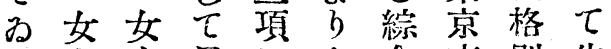

る杂胃に含合别生

しを、る分優し小心育

- 示中に類れ $九$ 學渗せ

又し等、しる、柲をし

概七各。身兒發加

しょる學各の體童見を

て る O 年學、全本し調

、。男を年同體均得垈

優 要一通男等の發なし

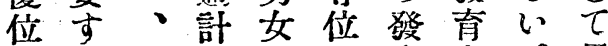

る るし別の充表。見

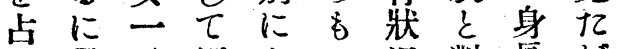

め男: 優よ O 況邺長加

て は劣れつ、加照、

居女れるて劣らし體こ

る

の男此比胸者 
卒優をつ況氮をるるか

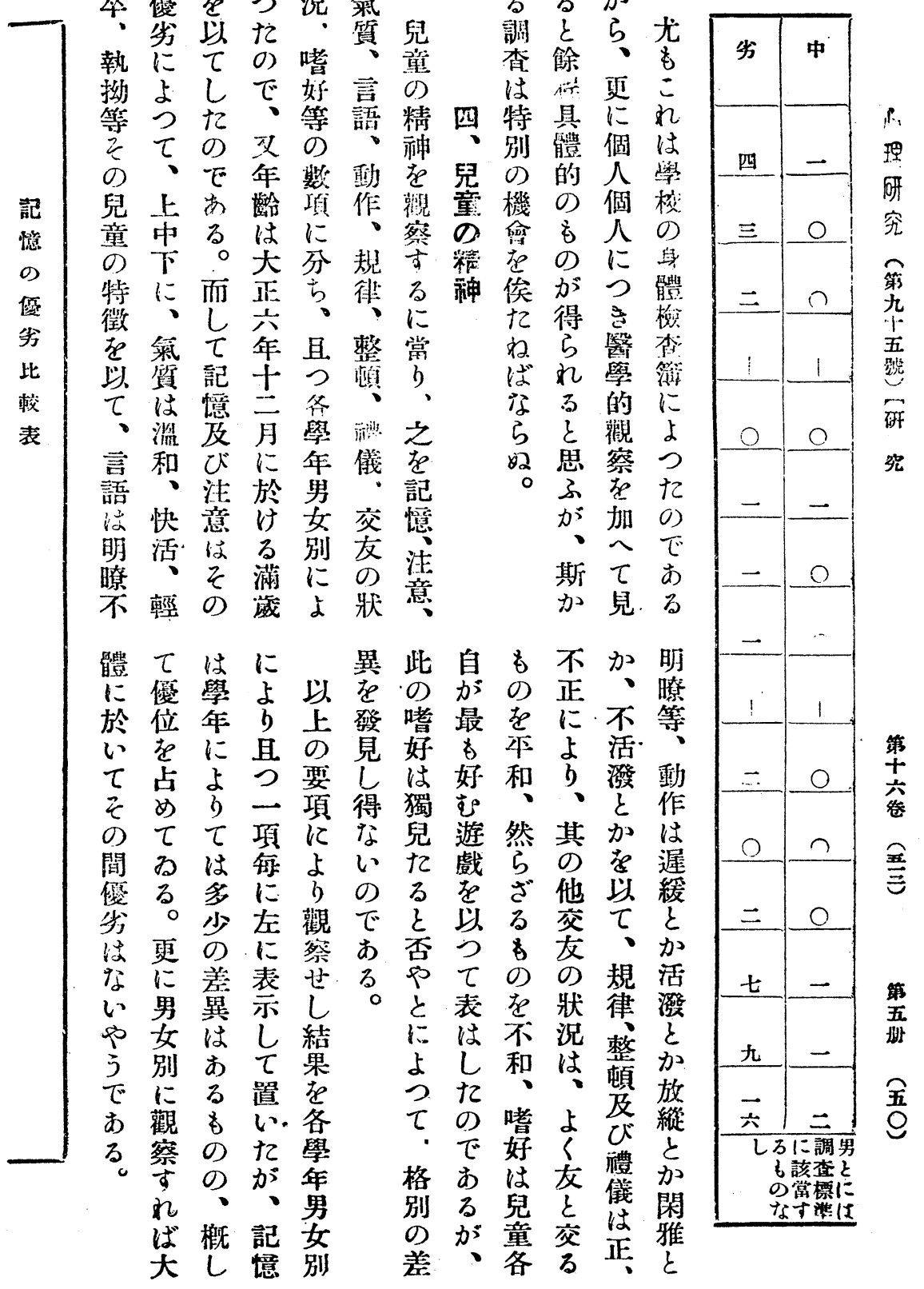




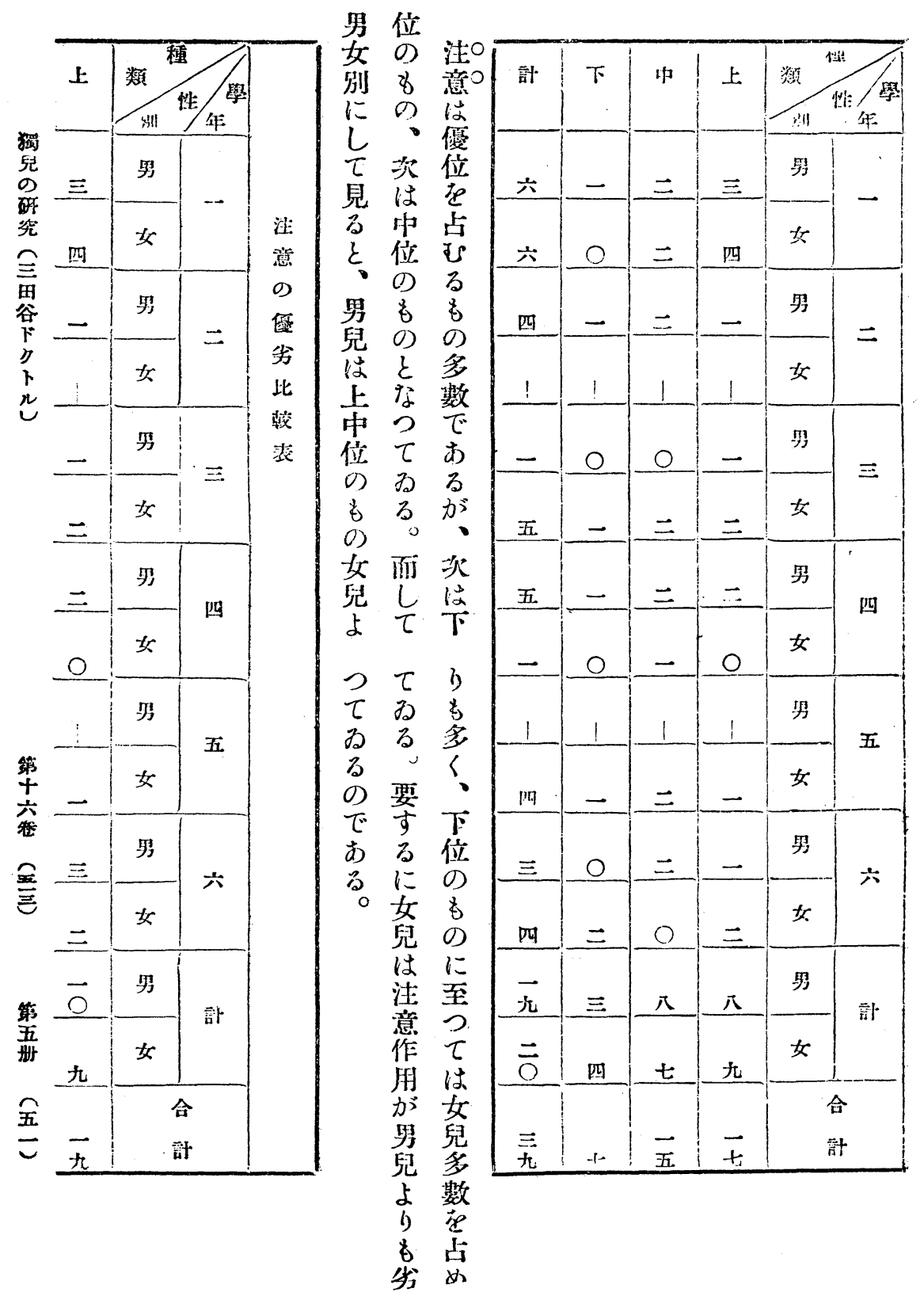




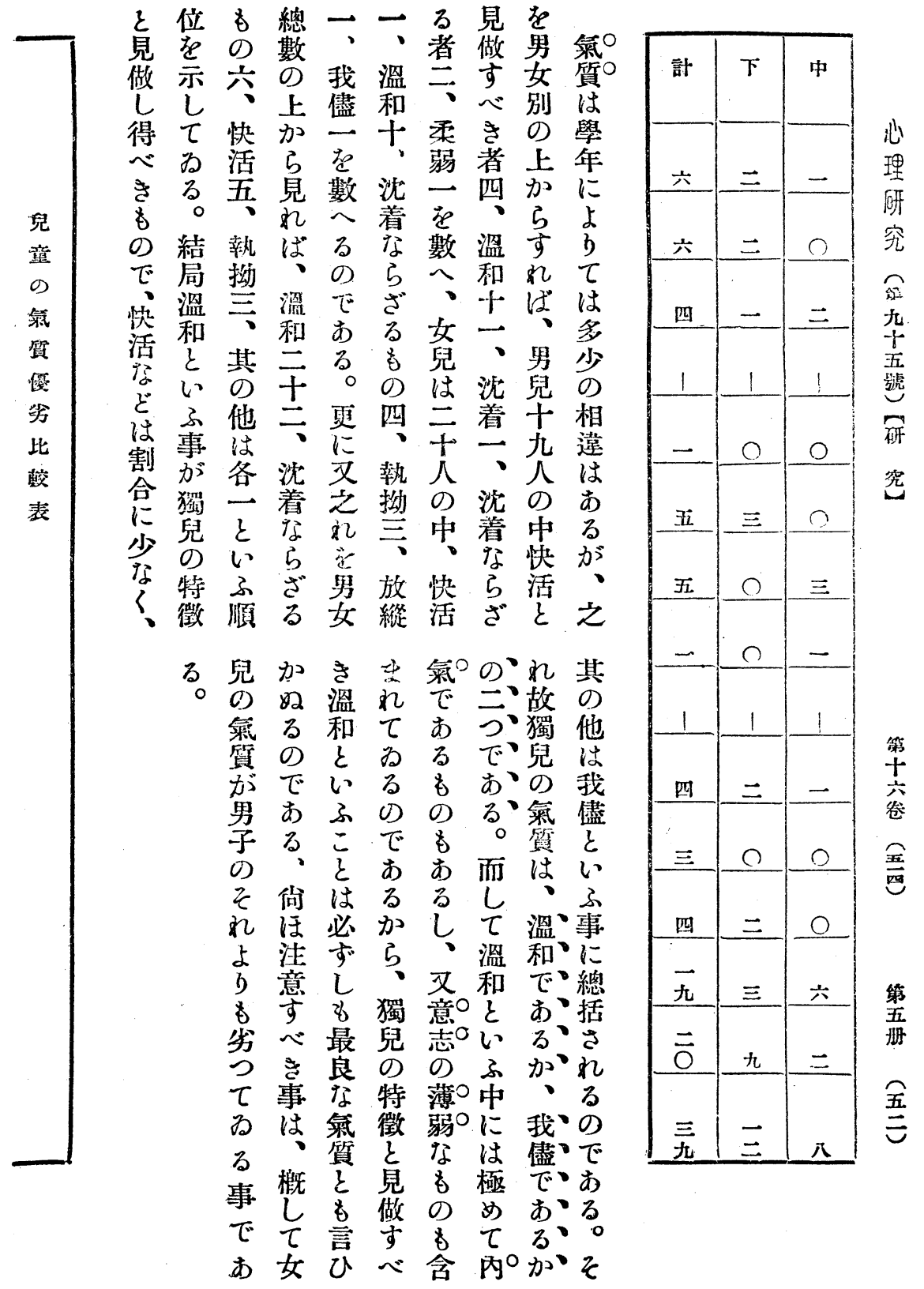




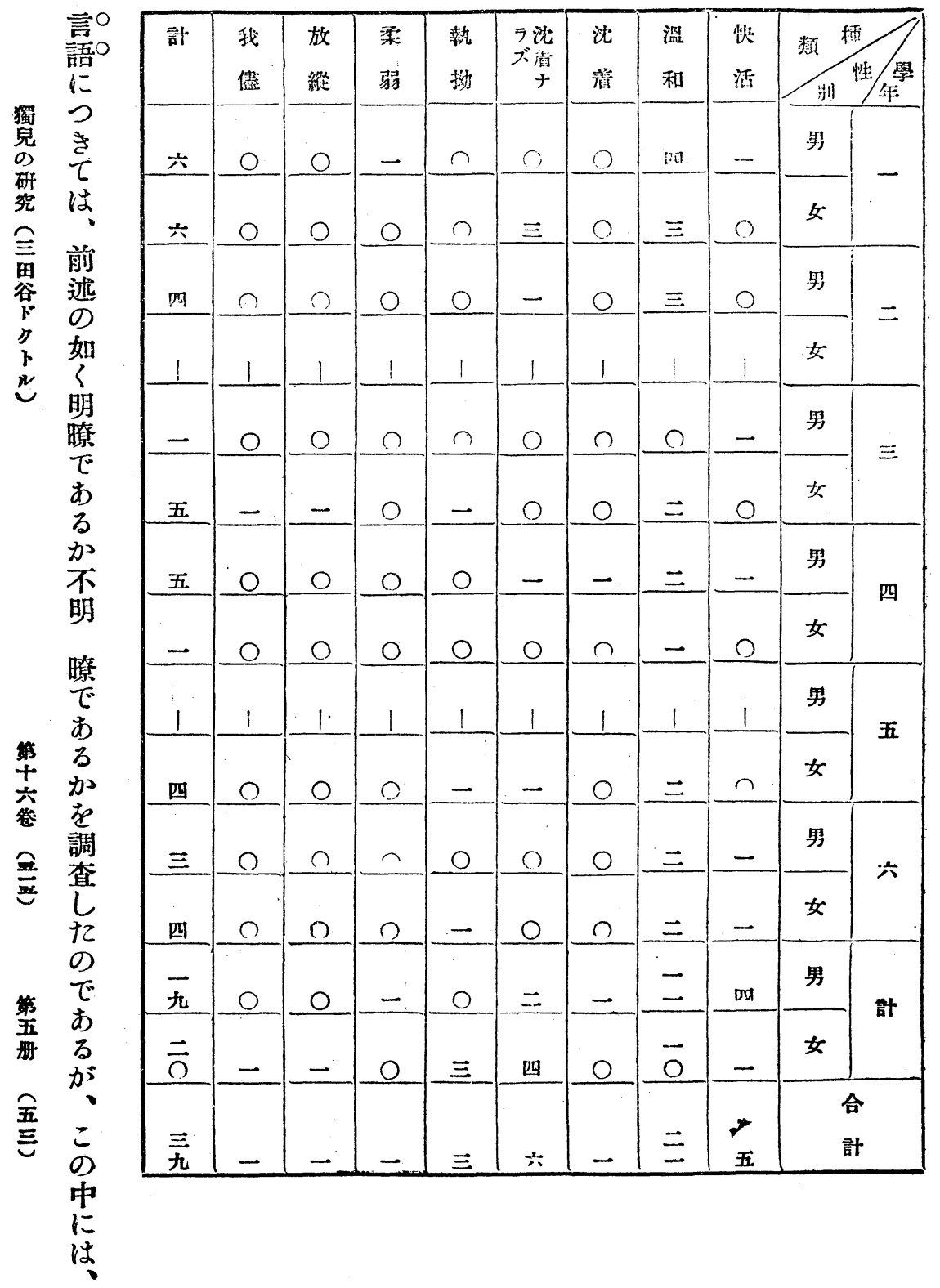



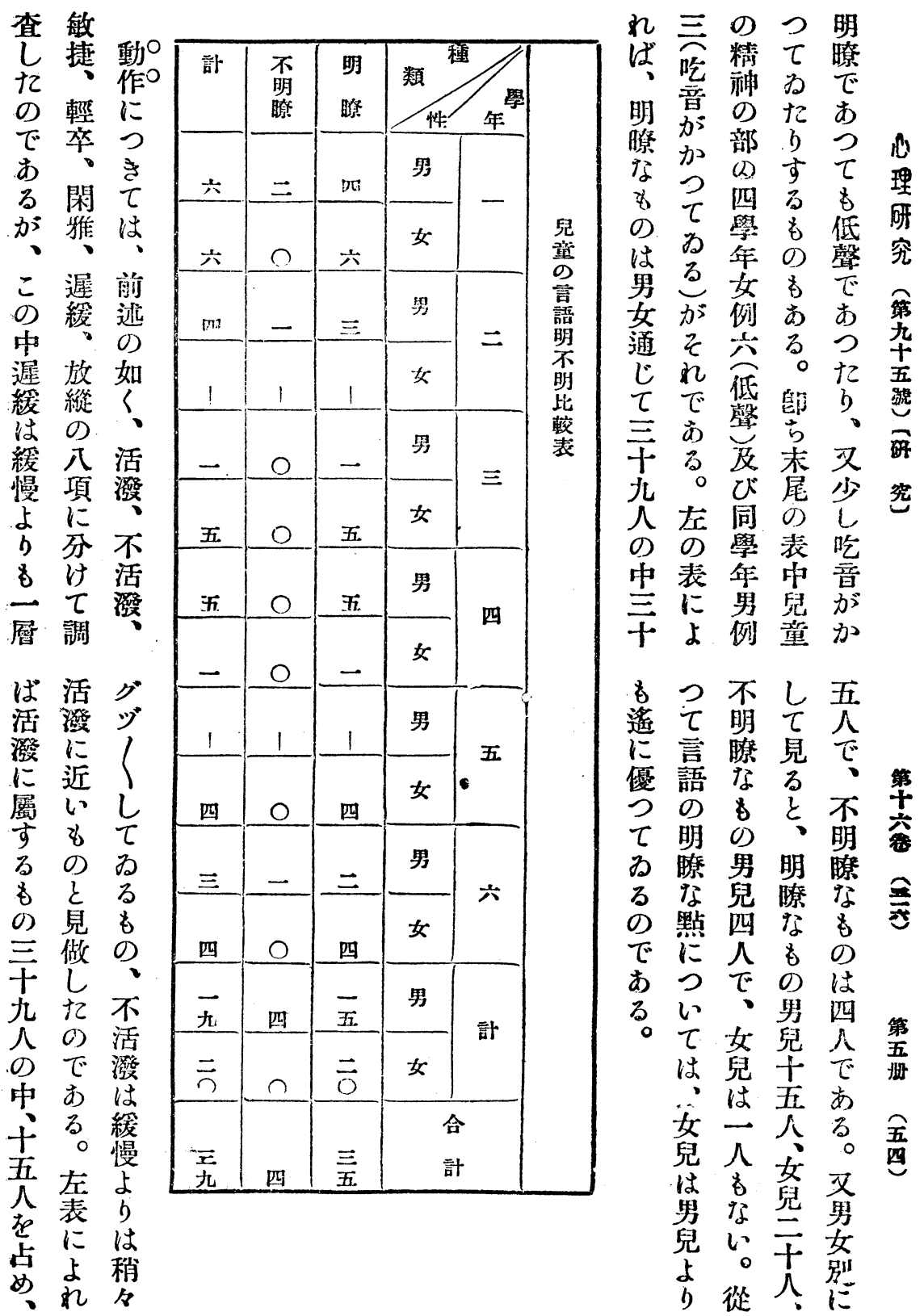


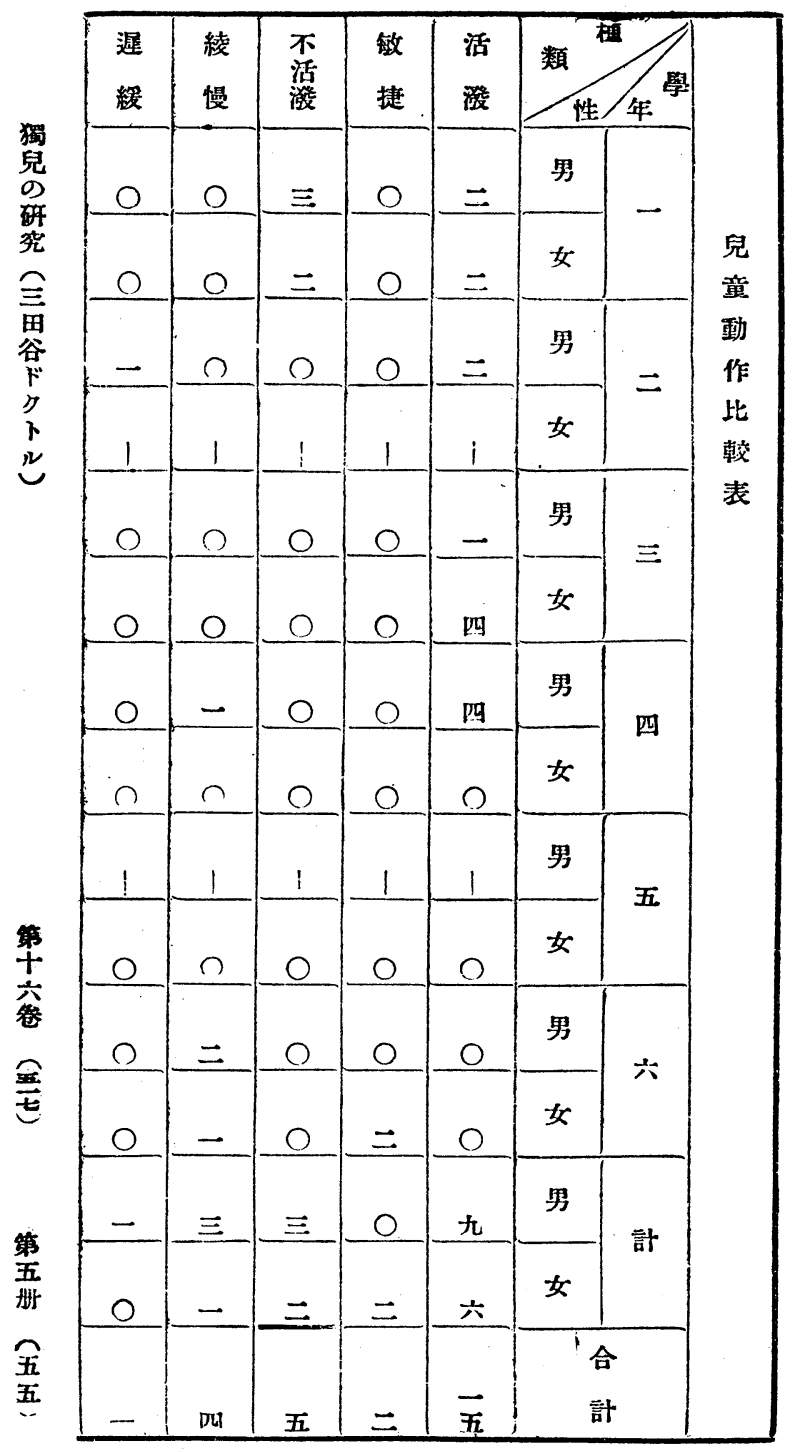

く男而は次

、兒し敏は

閉上捷輕

雅 3 活 卒

は潑放、

女女は縱不

兒兒第方，活

のに一同潑

み多位敏

にくで、次

緩男最は

放慢兒寻緩

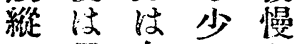

男女なと

男兒兒き闑

兒かには雅

の好住避

み兒り緩か

によ・で同

乌輕 あ 數

又る卒るで

痋多法。次

があやる緩

男らうる

兒引に事男

に。思 $\xi$ 兒

多郎は、心

いち䦥み

事輕る雅で

で卒が斻あ

あか、女る

る女之兒。

。兒のの活

に他獨潑

、占は

不大厄゙男

活にあ兒

潑注る加

- 意事女

緩 す

慢べは

・き當優

䈠剚然祭 


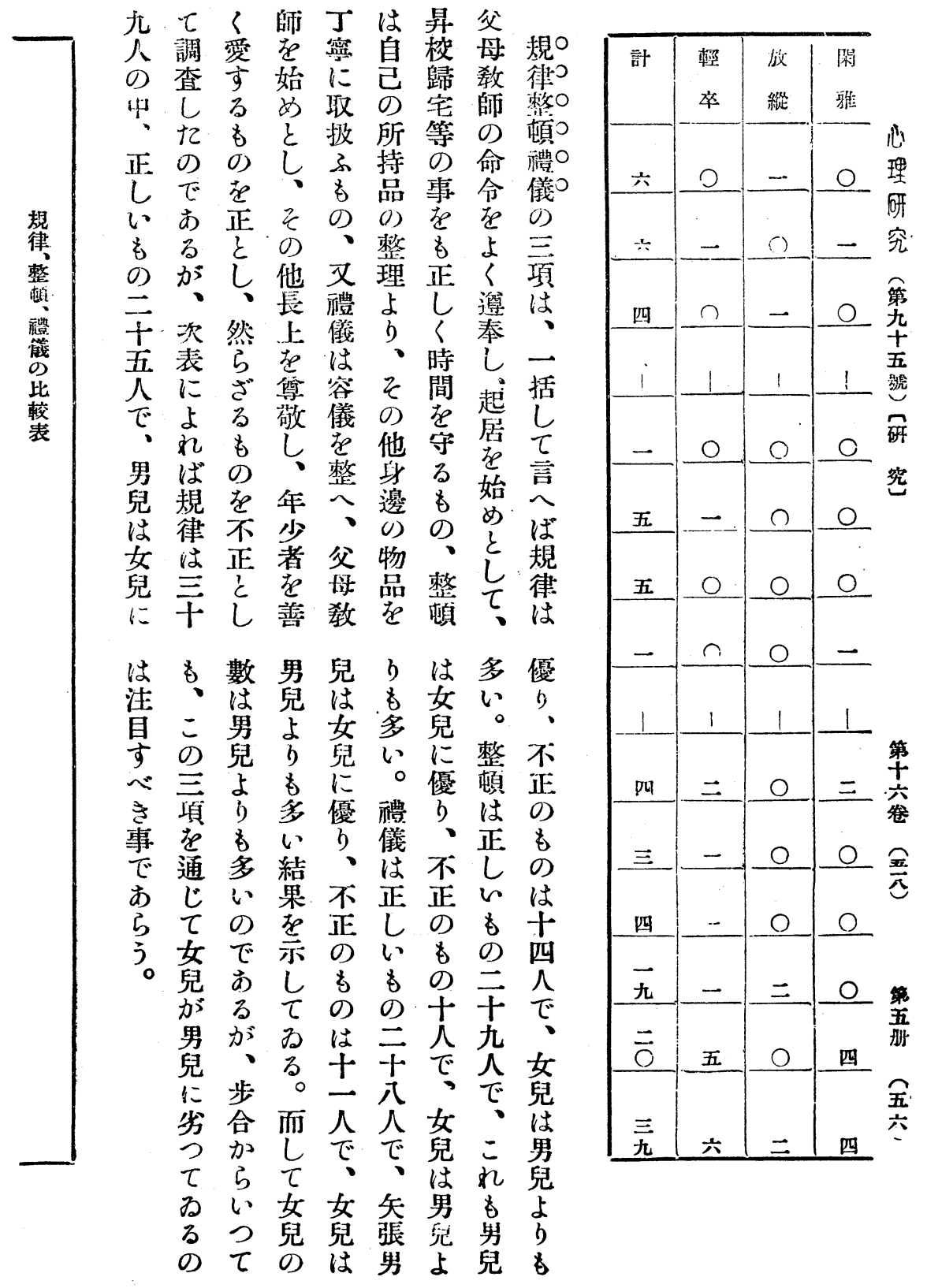




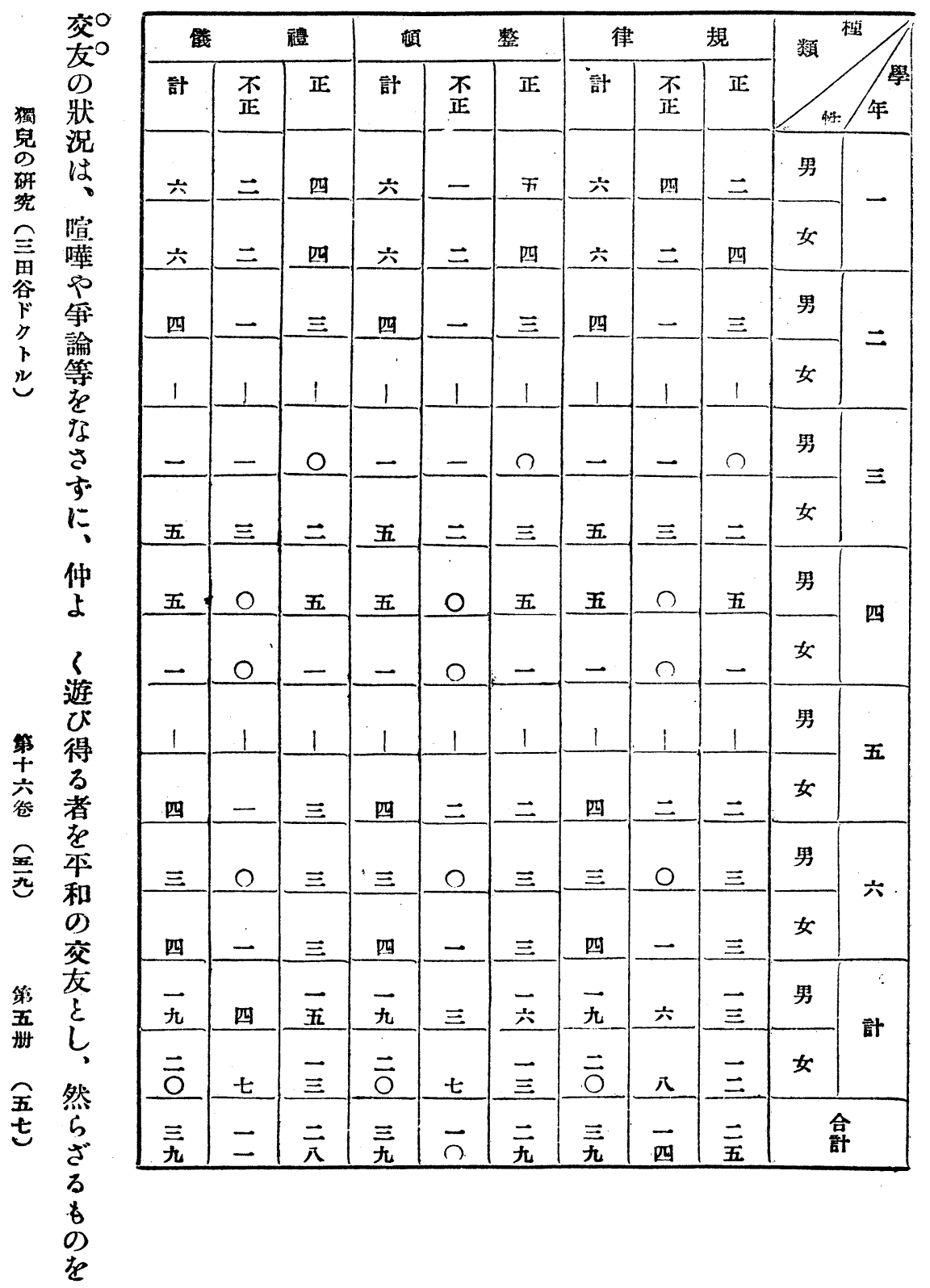




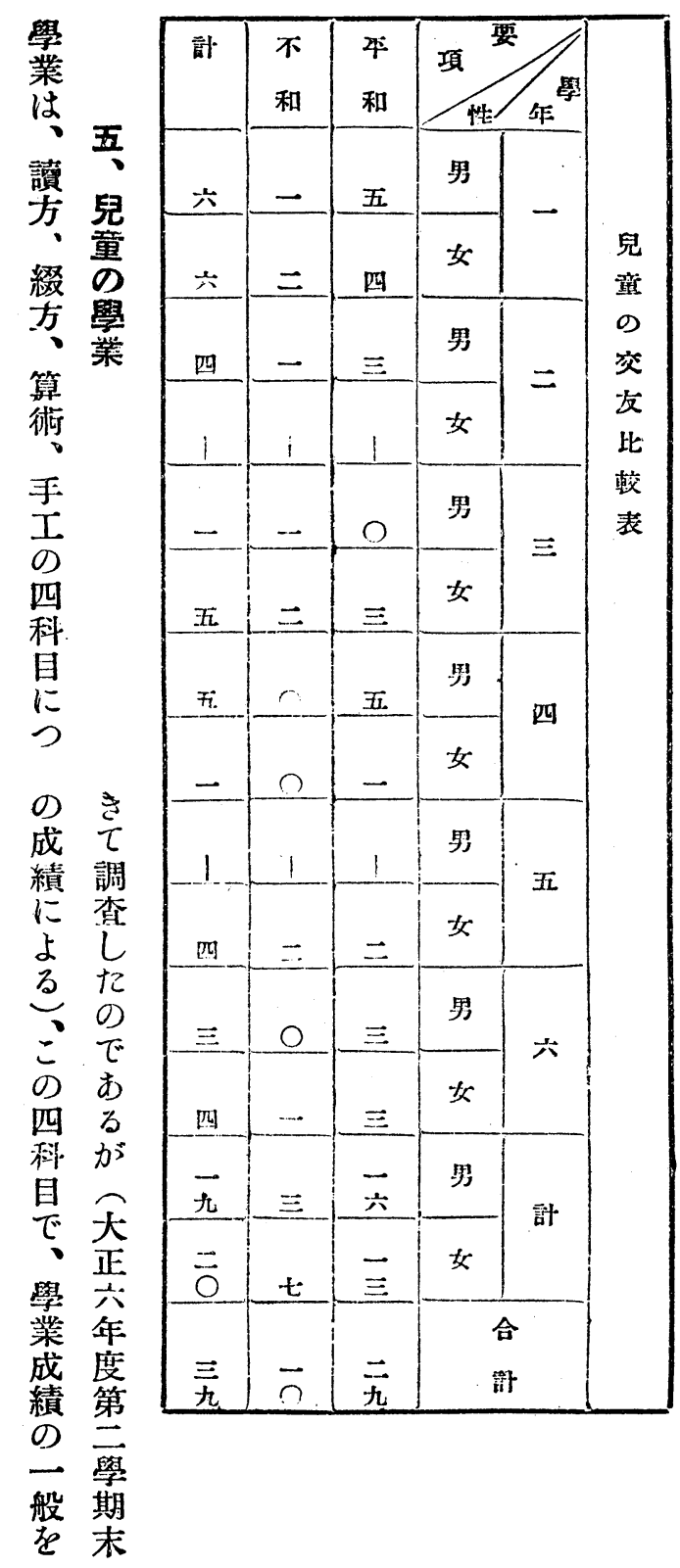

ちあへすの不 得るば友友和

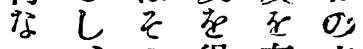
い、の 得有 の又間難し妄心 は獨に心泟理

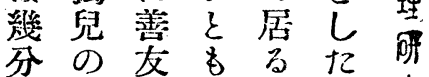
分の友篦限当古究 我 特 恐限々 加公 儘徵友 心し區心ら和卆 及七 別。高小吾

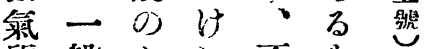

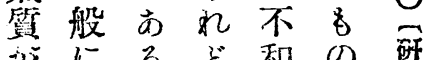
かにるど和の 研

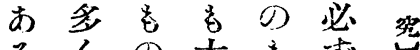
るくの大き市 かのは體のし 与友勿放必为 で艺論らず多 あ有で云しく でいい愿友る はの○りを。 称女、成左 加、兒不し表等 万男肪和得に亲 う兒男のるつ突

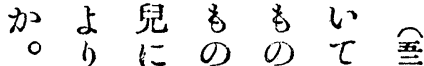
比结三自严 雅し十+れ 量て人九ば 劣本范算 るの兒 “九 萺は、人金 の友男界の芯 加在兒兒中 あ成占浪本 了し 与。和 加得专兒 0 らな多に卒 


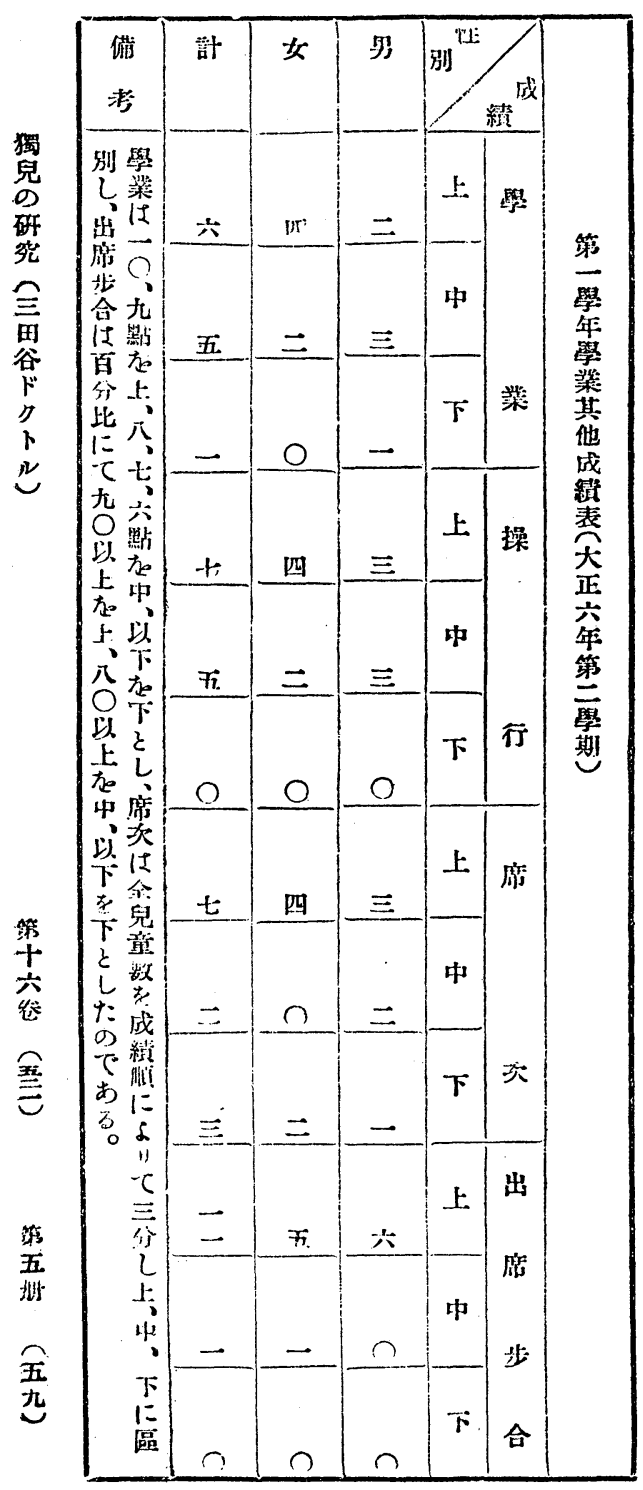

が目末にと窅 (a) に尾つ操知 左第上兒き行し

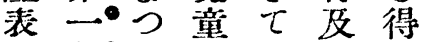
に學て 學のひる 上年・䛠業參出。 れ企明表洘渻の

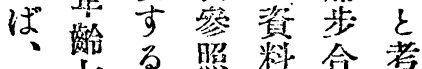
出旨 。 照料合考

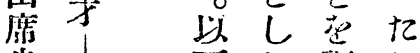
步市年䙘加 合分各に督 性學過した 男は、年“危たあ 兒男男な は女㚣心标。 女各別 兒宍及委成水 に名びし績に 優古學く讘麻 与る科は查次

中の精人て通そ 例養神 $あ$ おじの 二笲のるる總他 參さ發が。心性 照れ達 、併て 女 てをこしの兒 わ秋獨哭 るくは汇男 のな身學於兒 でく體業てに あ のに優 る家發於位 つ

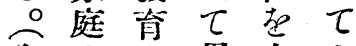
䨔の总古る 第地劣兒就る 第位宁下 而 表下为位るし 第位る の当て 學 實 年親又一數 不 


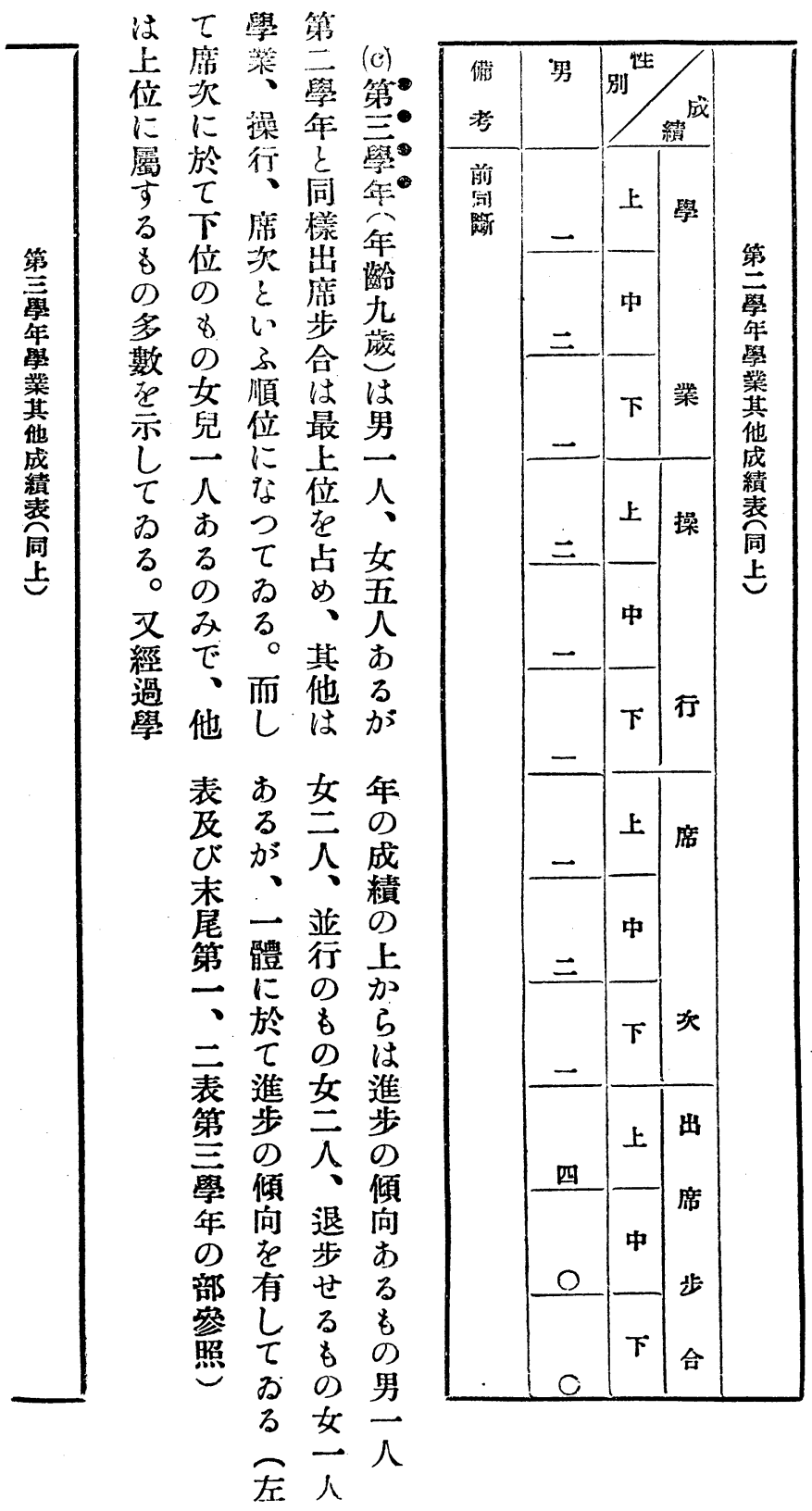

業 出

c 应 (b)

席步第。

次 合

と の 學・

心成年・理

了績年研

位隼龄究

によ父。

方第

つしは卆

七く男五

る、兒摅

る次の研

而操四

乙 行人

$\tau$ 、で

こ次 あ

礼學方

學 點 綜

業加合

表 5 乙

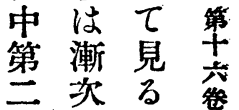

學鹪

の の成音

部傾 績

參向は

照秀位䈏

$\tau$ 屬

る ᄂ 公

을

末 過

尾 學

兒 年

童の 


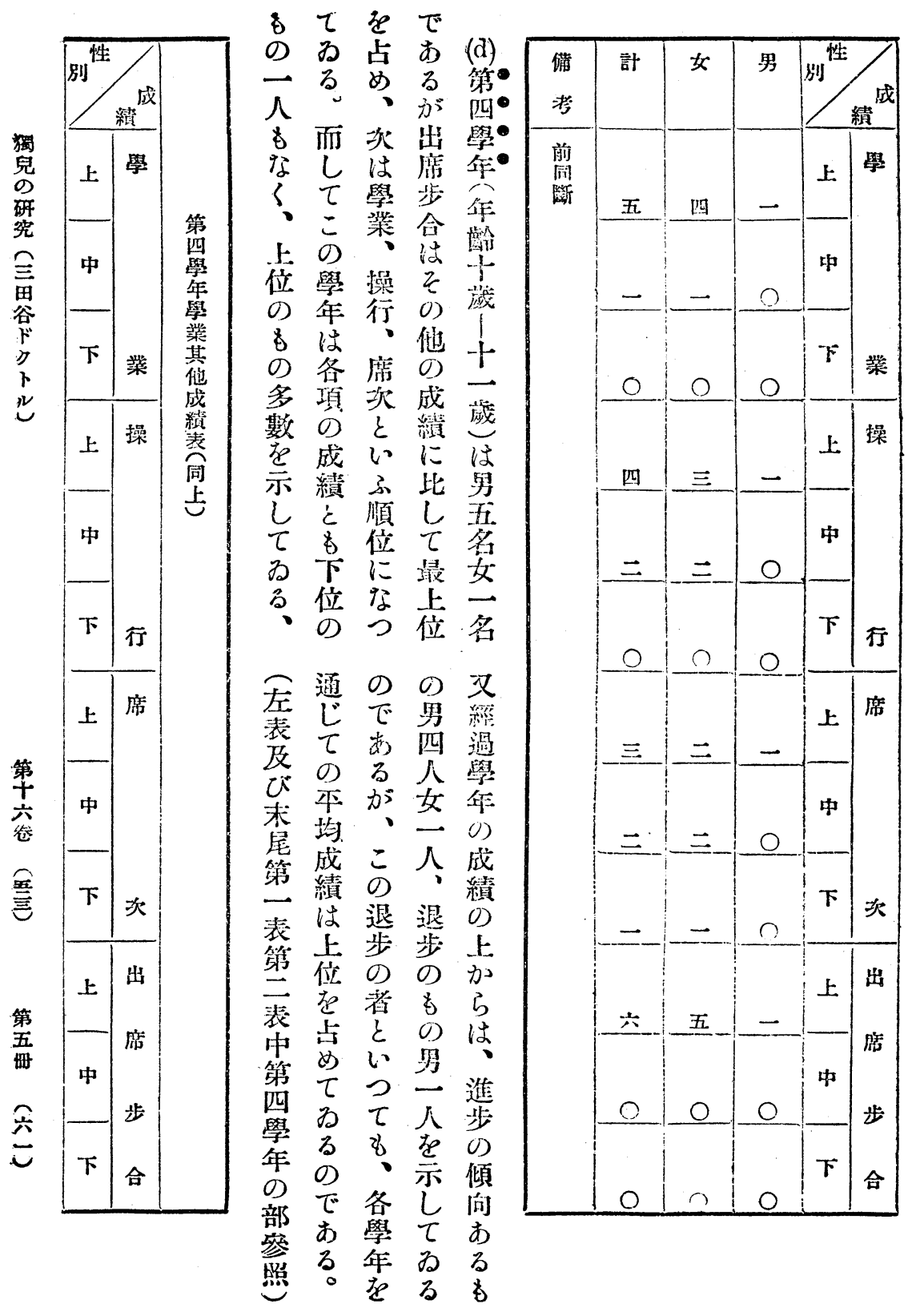




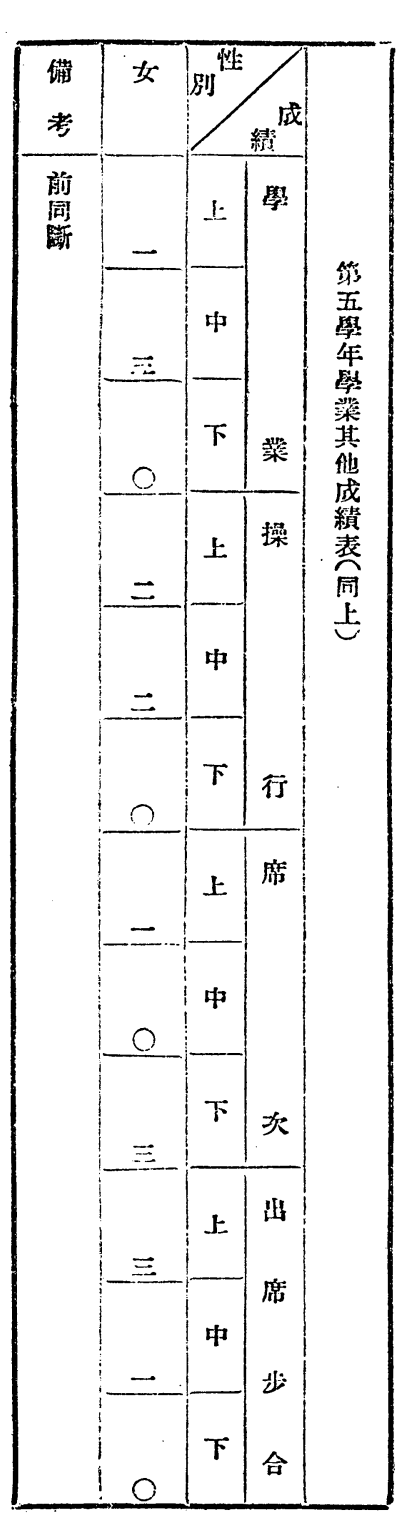

下儿學查

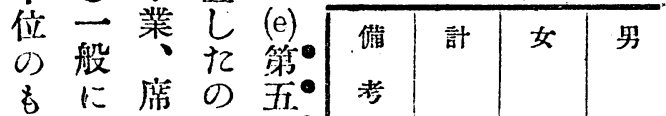

の成次で學。

は績 と古年・前

一はいる先

八少及加年

* 万順、萃

な

いる素成葴

刃心し續住

經併、は女

過し前、兒

學各述出四

年項 の 应名

のの各步に

成成學合 0

績縝年操 心

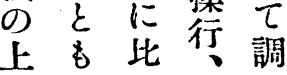

照 の令

d)

恶 行

左步

表、の

及 而 傾

び向

末市

尾のる

第成

三績 0

表氺一

中中人

第 位 の

五にみ

學屬で

年 し 之

五 - 四

究

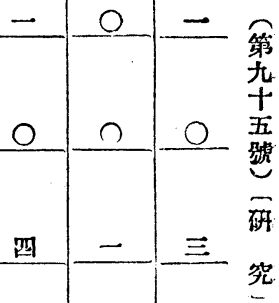

部るは 


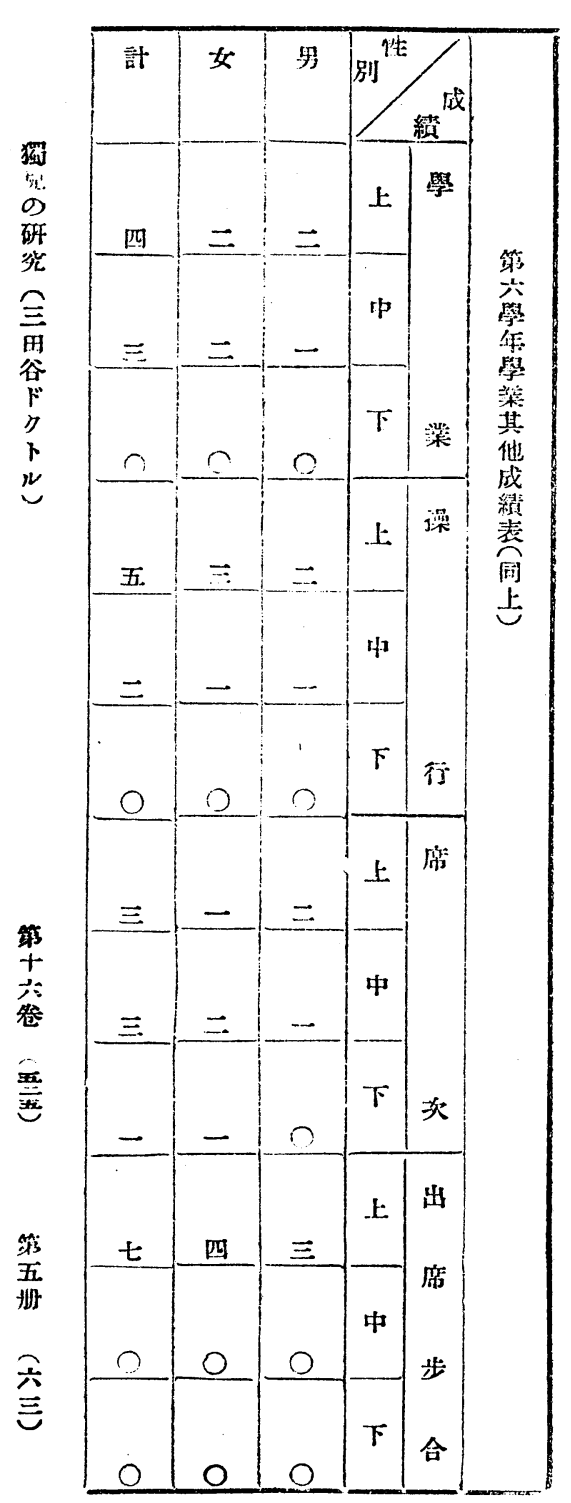

二向七女位を名

名市わ兒星に(f)

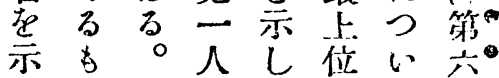
LO 及市衣學。 て男經るるし調倠。

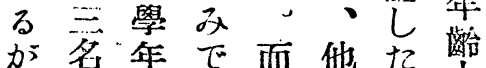
が采年で而他た灌 こ女成他它操で兰 の兒績の、行お藏 行要上各席學召士 の、かはに業、志 成並 5 上於出墭 綪行は位借席は 者の、多下次步男 た進数 位 $\varepsilon$ 合 るの步在のい名 女女の占をふ成女 兒兒傾めの順績叫

一に焦作かの

二步二支。輕料名

表の學營草神は 中傾年んでに年 第问上であ於趁 共をるるるて十 學示六宁少三 年专學、家就相 ○)年地庭㤘で 部過迄位に射 例ぎ席は於法體 五な炏中て意0 參いは等は夜

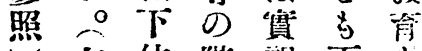
左位階親下急 表に級に位よ 及此で養心 びあ充屬の 末 、る 第篗而、動る 


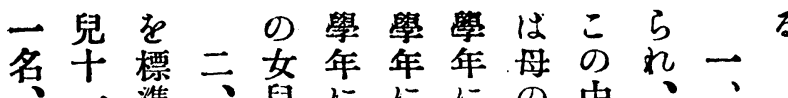

下名準、兒兒に盆男に而兒古

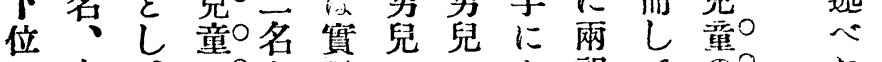

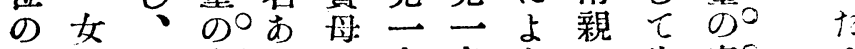

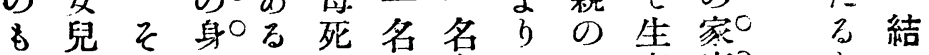

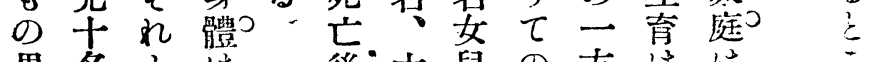

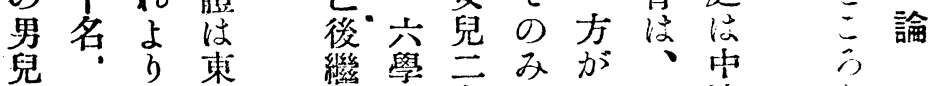

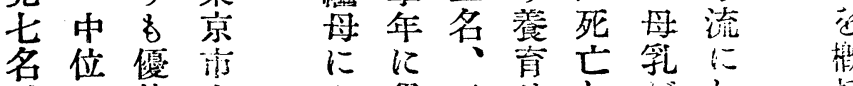

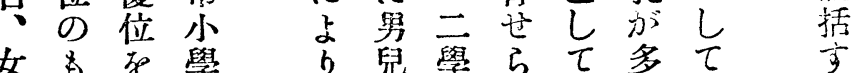

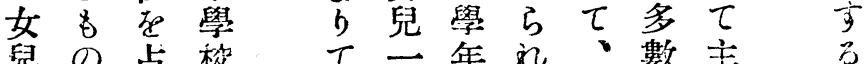

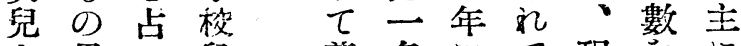

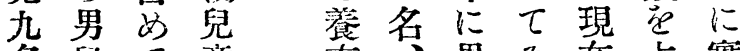

名兒七童充男わ在占實

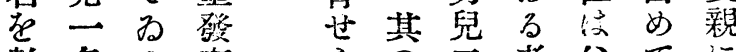

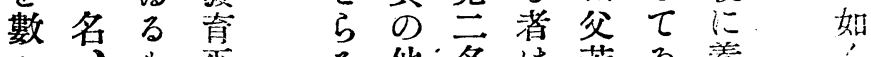

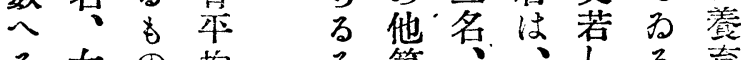

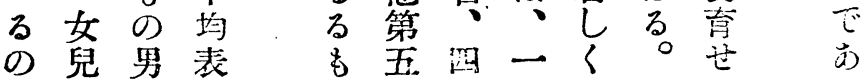

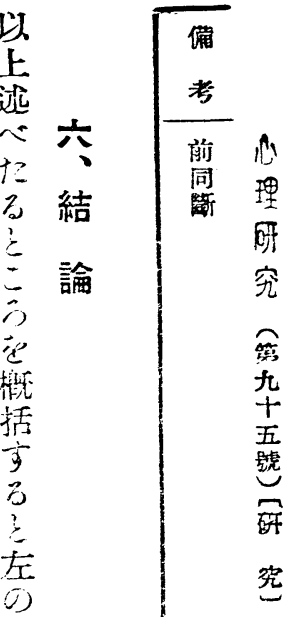

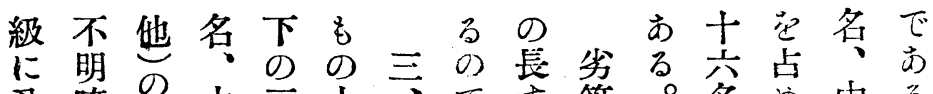

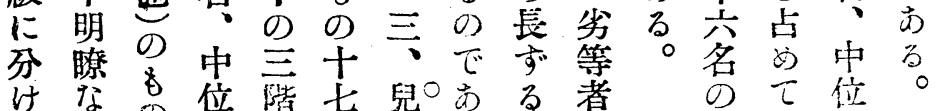

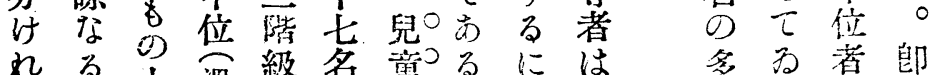

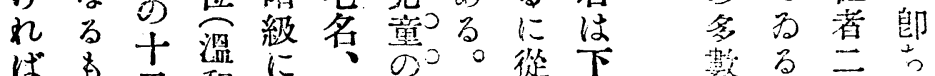

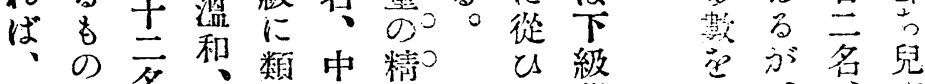

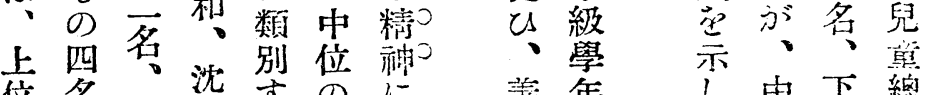
位名言染省のに等省總

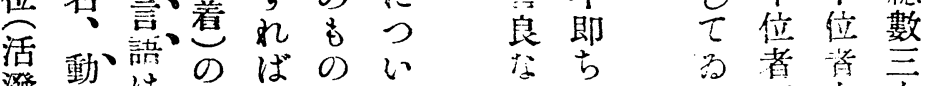

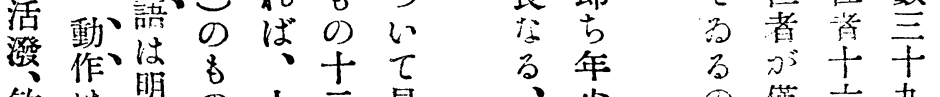

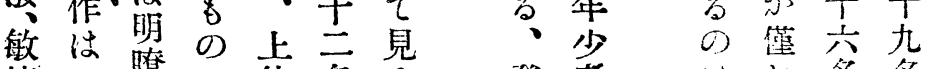
捷己暸三位名当留者台名名

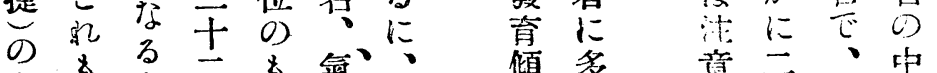

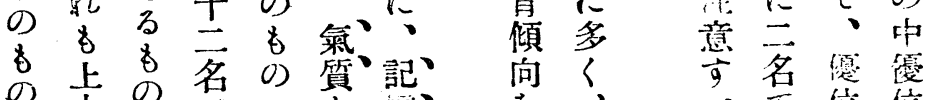

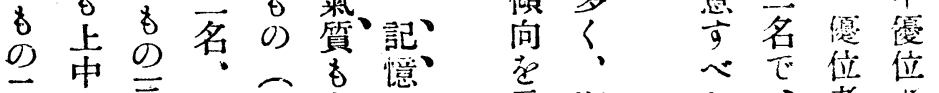

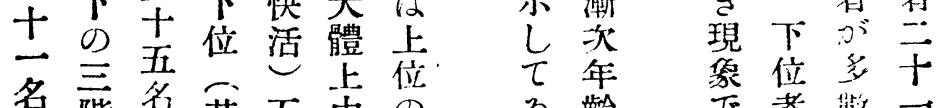




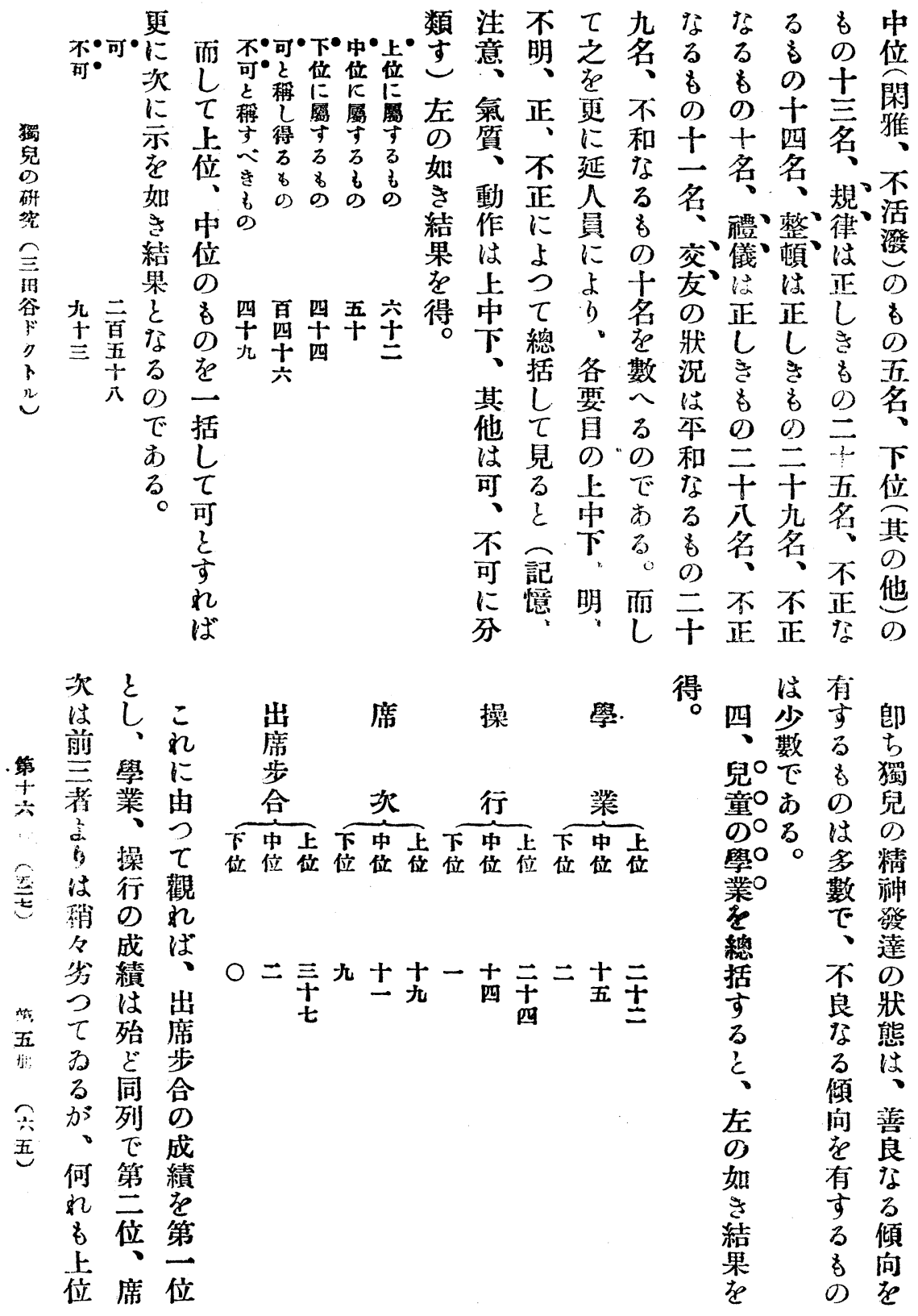




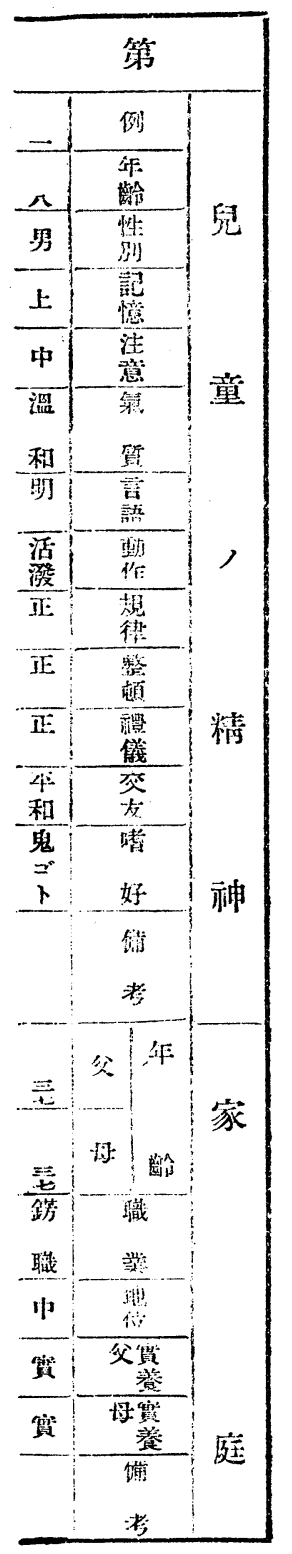

か上るか方身縝 のに ら位べ、面○體のの次ま屬

のく本の○の如にの方

學。、均發發何身の へ

業のけし達育尼體極き心

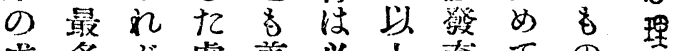
第

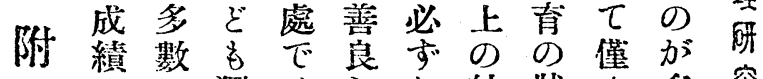
ので獨注なし、結狀少多究

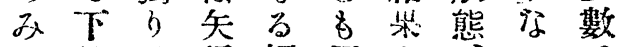

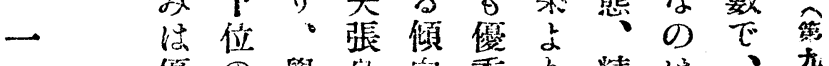

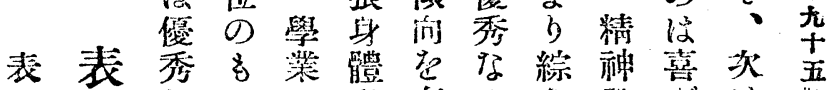

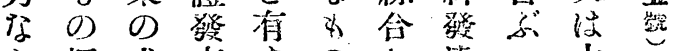

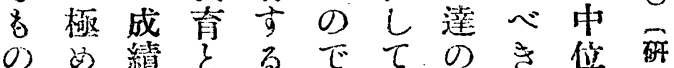
とてに同离は断牀現究

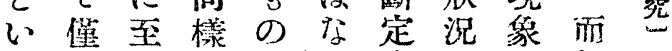

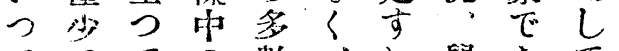

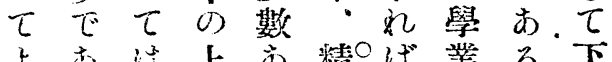

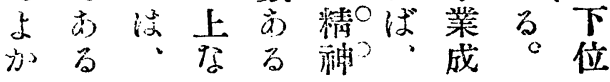
裴多。に成机字怘 梦天供緼心亡理獨う るの のし尼を思學兒

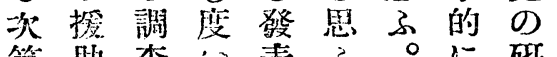
第助查的表方。に研

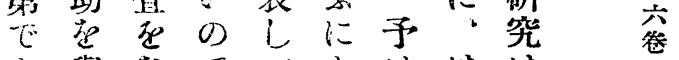
市與なでっよははは

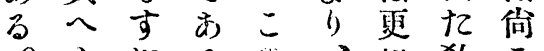
与に斿、呚こ

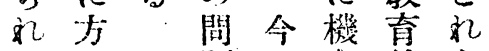
纪 $b$ 題舀俞的老 ○织只蛋に詳 記は興已得調細 乙知哦 0 ) $\tau$ 隹に 七度前此吉觀 愿宫有提等风察 威善るし 調 興 謝次人查唩學

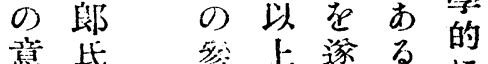
意此等上遂る的 


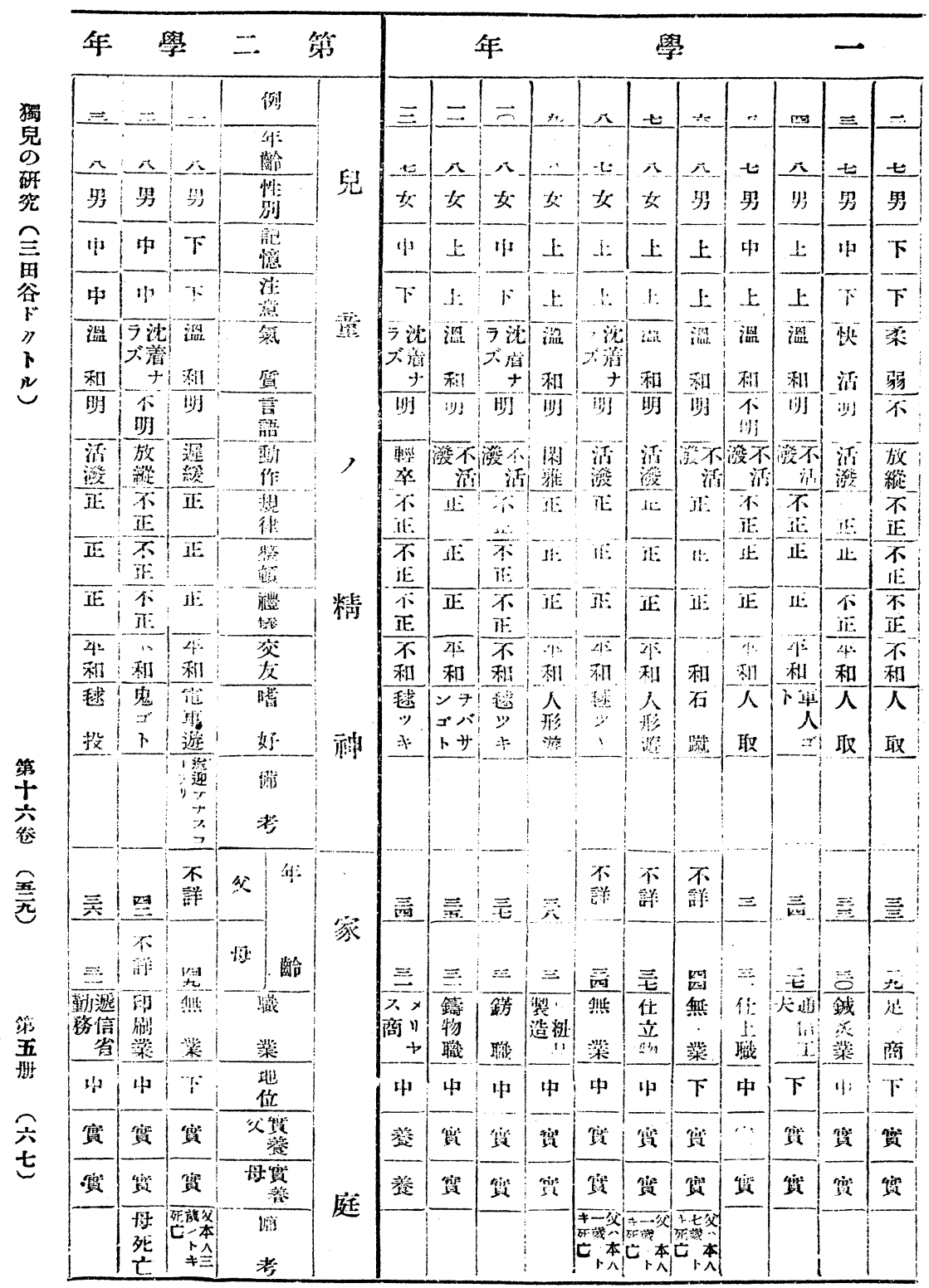




\begin{tabular}{|c|c|c|c|c|c|c|c|c|c|c|c|c|c|c|}
\hline \multicolumn{3}{|c|}{ 學 } & 四 & \multicolumn{2}{|c|}{ 第 } & \multicolumn{3}{|c|}{ 年 } & \multicolumn{2}{|l|}{ 學 } & $\equiv$ & \multicolumn{2}{|l|}{ 第 } & \\
\hline$D G$ & $\equiv$ & $=$ & & 例 & & $\therefore$ & $\pi$ & $m$ & $\equiv$ & $=$ & -. & 例 & & 四 \\
\hline $\overrightarrow{0}$ & $\overline{0}$ & $=$ & 20 & $\begin{array}{l}\text { 年 } \\
\text { 路命 }\end{array}$ & & $r_{1}$ & $t_{-}$ & 出 & r & $\pi$ & $\therefore$ & $\begin{array}{l}\text { 年 } \\
\text { 齢 }\end{array}$ & & $r$ \\
\hline 男 & 男 & 男 & 男 & 性 & 录 & 女 & 尔 & 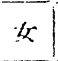 & 女 & 女 & 星 & 監 & 兒 & 照 \\
\hline 中 & 上 & 上 & 中 & 蓝 & & 中 & 上 & t阝 & 上 & 下 & I & 憵 & & 上 \\
\hline 上 & 上 & 中 & 少 & 注 & & 上. & 下 & 下 & t & 下 & 1. & $\begin{array}{l}\text { 注 } \\
\text { 意 }\end{array}$ & & 上 \\
\hline 煴 & 温 & 然 & 沈 & 氣 & 童 & $\overline{\text { 溜 }}$ & 我 & 放 & 泪 & 執 & 误 & 氟 & 童 & $\sqrt{\text { 㳭 }}$ \\
\hline 和 & 和 & 活 & 筧 & 質 & & 和 & 貛 & 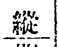 & 和 & 抄 & 湉 & 筧 & & 和 \\
\hline 然 & 明 & 证了 & 明 & 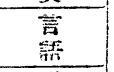 & & 时 & 明 & 刑 & 明 & 明 & 明 & $\begin{array}{c}\text { 言 } \\
\text { 語 } \\
\end{array}$ & & 明 \\
\hline $\begin{array}{l}\text { 活 } \\
\text { 潑 } \\
\end{array}$ & $\begin{array}{l}\text { 活 } \\
\text { 洐 } \\
\end{array}$ & $\begin{array}{l}\text { 活 } \\
\text { 潑 }\end{array}$ & $\begin{array}{l}\text { 緩 } \\
\text { 慢 }\end{array}$ & $\begin{array}{l}\text { 敦 } \\
\text { 作 } \\
\end{array}$ & ノ & $\begin{array}{l}\text { 活 } \\
\text { 激 } \\
\end{array}$ & $\begin{array}{l}\text { 活 } \\
\text { 潹 } \\
\end{array}$ & 灌 & 活 & $\begin{array}{l}\text { 整 } \\
\text { 卒 } \\
\end{array}$ & $\begin{array}{l}\text { 活 } \\
\text { 滩 } \\
\end{array}$ & $\begin{array}{l}\text { 動 } \\
\text { 作 }\end{array}$ & ᄀ & \begin{tabular}{|l} 
濩 \\
潑 \\
\end{tabular} \\
\hline 正 & 证 & it: & 正 & 賛 & & JE & 等 & $\begin{array}{l}\text { 不 } \\
\text { iE }\end{array}$ & 正 & $\begin{array}{l}\text { 不 } \\
\text { 正 }\end{array}$ & 正 & 賛 & & IE \\
\hline IIE & 正 & 正 & $\mathrm{IE}$ & $\begin{array}{l}\text { 整 } \\
\text { 頓 }\end{array}$ & & IIL & $\overline{J E}$ & $\begin{array}{l}\text { 促 } \\
\text { in }\end{array}$ & ii: & 正 & $\begin{array}{l}\text { 不 } \\
\text { 正 }\end{array}$ & $\begin{array}{l}\text { 整 } \\
\text { 䖝面 }\end{array}$ & & $\overline{\text { II }}$ \\
\hline 仩 & $\overline{\text { IFE. }}$ & II: & $\overline{\mathrm{I}}$ & 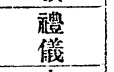 & 椿 & II: & 交 & $\begin{array}{l}\text { 不 } \\
\text { if }\end{array}$ & IE & 不 & 不 & $\begin{array}{l}\text { 禮 } \\
\text { 㦈 } \\
\end{array}$ & 精 & ㅍ: \\
\hline $\begin{array}{l}\text { 平 } \\
\text { 和 }\end{array}$ & $\begin{array}{l}4 \\
\text { 和 } \\
\end{array}$ & 平 & $\begin{array}{l}4 \\
\text { 和 }\end{array}$ & 变 & & 和 & $\begin{array}{l}\text { 平 } \\
\text { 和 }\end{array}$ & 不 & $\begin{array}{l}\text { 本 } \\
\text { 和 }\end{array}$ & 和 & 和 & 䇾 & & $\begin{array}{l}\text { 平 } \\
\text { 和 }\end{array}$ \\
\hline $\begin{array}{l}\text { 锟 } \\
\text { 行 } \\
\text { 機 }\end{array}$ & 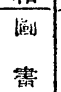 & $\begin{array}{l}\text { 飛 } \\
\text { 行 } \\
\text { 機 }\end{array}$ & $\begin{array}{l}\text { 散 } \\
\text { 步 }\end{array}$ & 考 & 神审 & $\begin{array}{c}\text { 人 } \\
\text { 形 } \\
\text { 游 }\end{array}$ & 不 & 全 & $\begin{array}{c}\text { 人 } \\
\text { 形 } \\
\text { 遊 }\end{array}$ & $\begin{array}{l}\text { 救 } \\
\% \\
\neq\end{array}$ & 等 & $\begin{array}{l}\text { 僣 } \\
\text { 好 }\end{array}$ & 秥 & $\begin{array}{l}\text { 石 } \\
\text { 踾 }\end{array}$ \\
\hline & & & & $\begin{array}{l}\text { 備 } \\
\text { 楛 }\end{array}$ & & & 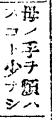 & 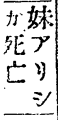 & 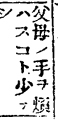 & 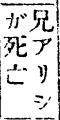 & & $\begin{array}{l}\text { 溜 } \\
\text { 考 }\end{array}$ & & \\
\hline F & $\equiv$ & 圆 & 畺 & 父 年 & & 瑟 & 瑟 & 范 & $\underline{E}$ & $\equiv$ & 哭 & 父 年 & & 至 \\
\hline$\equiv$ & 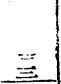 & 西 & 10 & \begin{tabular}{l|l|} 
& 䶣 \\
\end{tabular} & & Fi & 至 & $\vec{x}$ & 罗 & 䛛 & $\overline{\bar{t}}$ & 目 齡 & 水 & $=\dot{0}$ \\
\hline 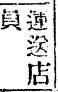 & 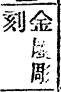 & 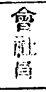 & 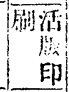 & $\begin{array}{l}\text { 職 } \\
\text { 菜 }\end{array}$ & & 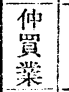 & $\begin{array}{l}\text { 鋶 } \\
\text { 礍 } \\
\text { 否 }\end{array}$ & 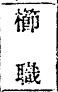 & $\begin{array}{l}\text { 倛 } \\
\text { 终 }\end{array}$ & 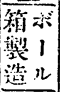 & 变 & 韱 & & $\begin{array}{l}\text { 贵潾 } \\
\text { 險服 } \\
\text { 洋 }\end{array}$ \\
\hline 中 & 中 & ゆ & 中 & $\begin{array}{l}\text { 跑 } \\
\text { 位 }\end{array}$ & & No & 中 & 中 & 巾 & 中 & 中 & $\begin{array}{l}\text { 地 } \\
\text { 位 }\end{array}$ & & 中 \\
\hline 實 & 貿 & 毊 & 䍿 & $\begin{array}{l}\text { 忞兾 } \\
\text { 盖 }\end{array}$ & & 贺: & 留 & 䔈 & 刻 & 貝 & 实 & $\begin{array}{l}\text { 文蜜 } \\
\text { 養 }\end{array}$ & & 露 \\
\hline 项 & 窝 & 養 & 樾 & $\begin{array}{r}\text { 母嵔 } \\
\text { 養 }\end{array}$ & $B$ & 筑 & 賽 & 睑 & 蕉 & 霓 & 赛 & $\begin{array}{l}\text { 母装 } \\
\text { 養 }\end{array}$ & 庭 & 攻 \\
\hline & & & & 剒 & 処 & 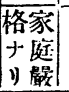 & 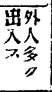 & & & & & $\begin{array}{l}\text { 備 } \\
\text { 洘 }\end{array}$ & & \\
\hline
\end{tabular}




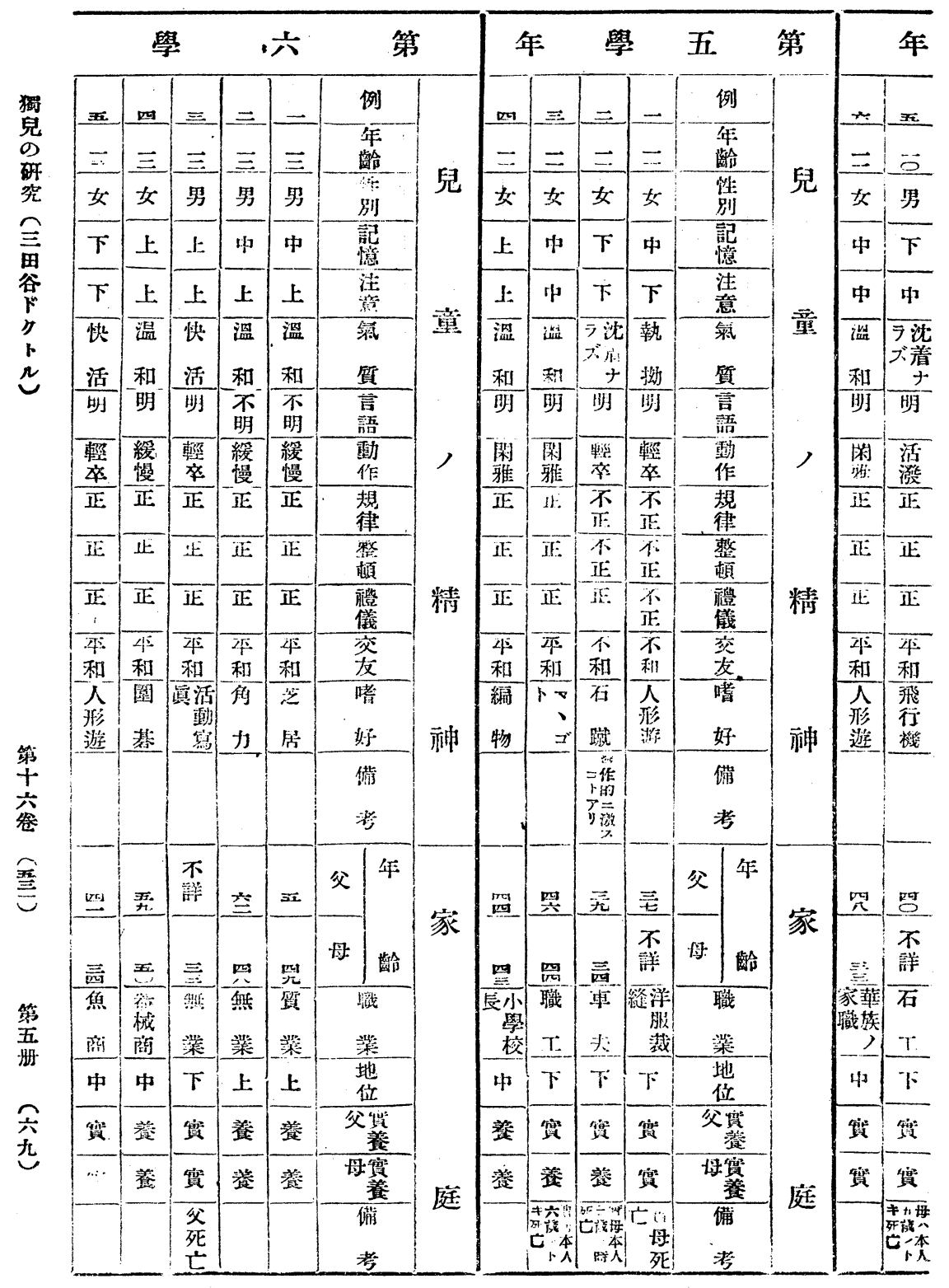




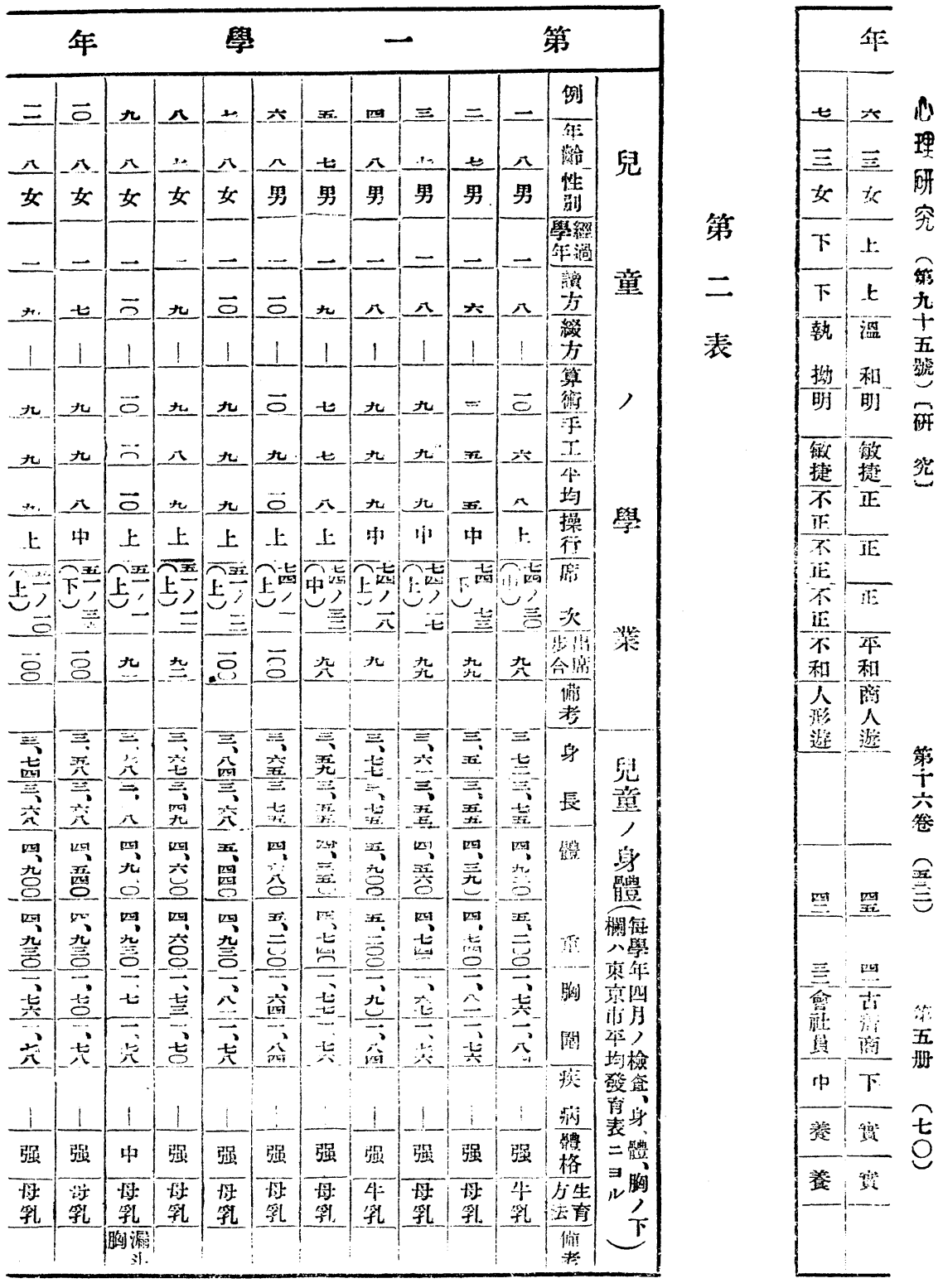




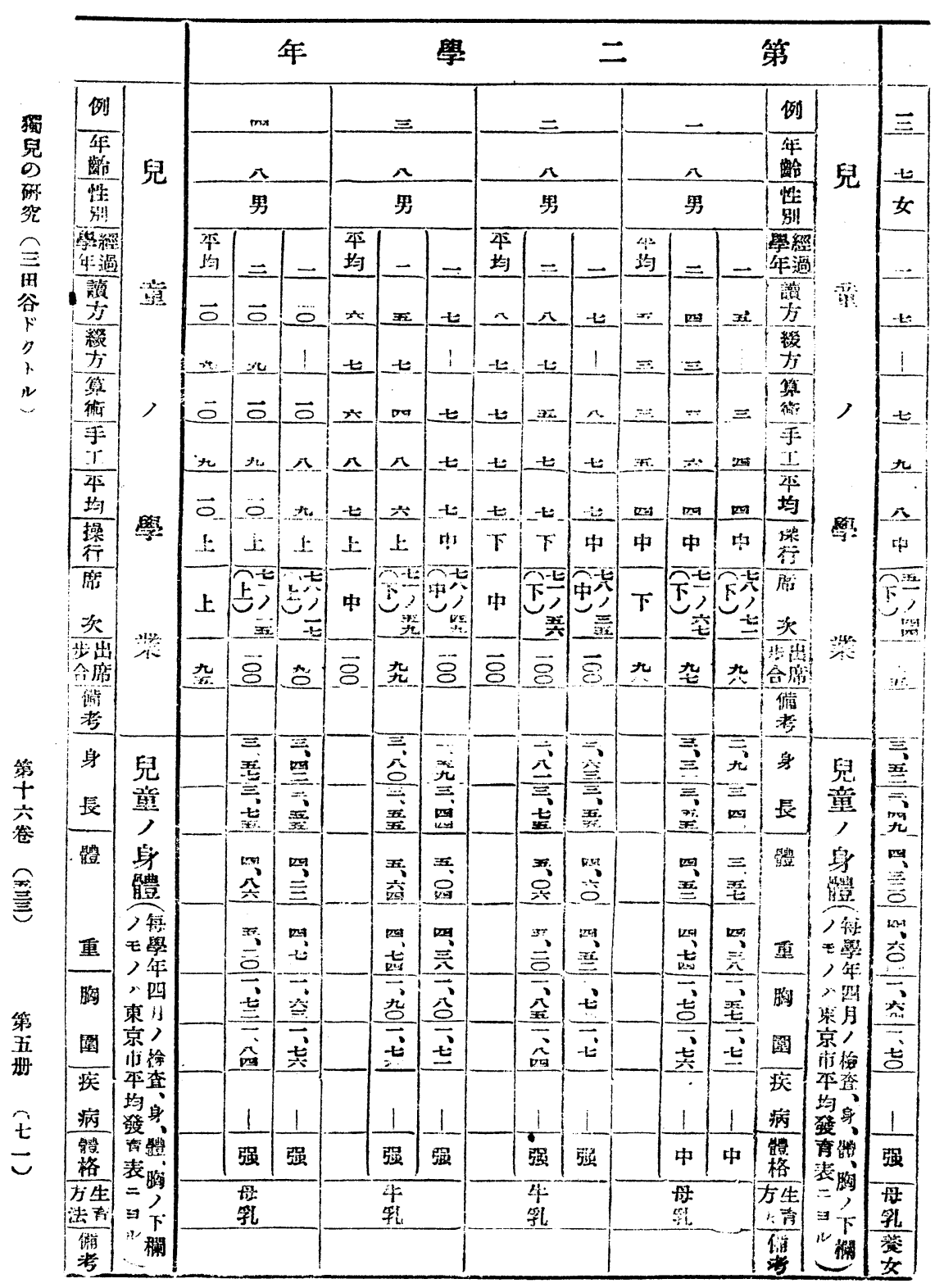




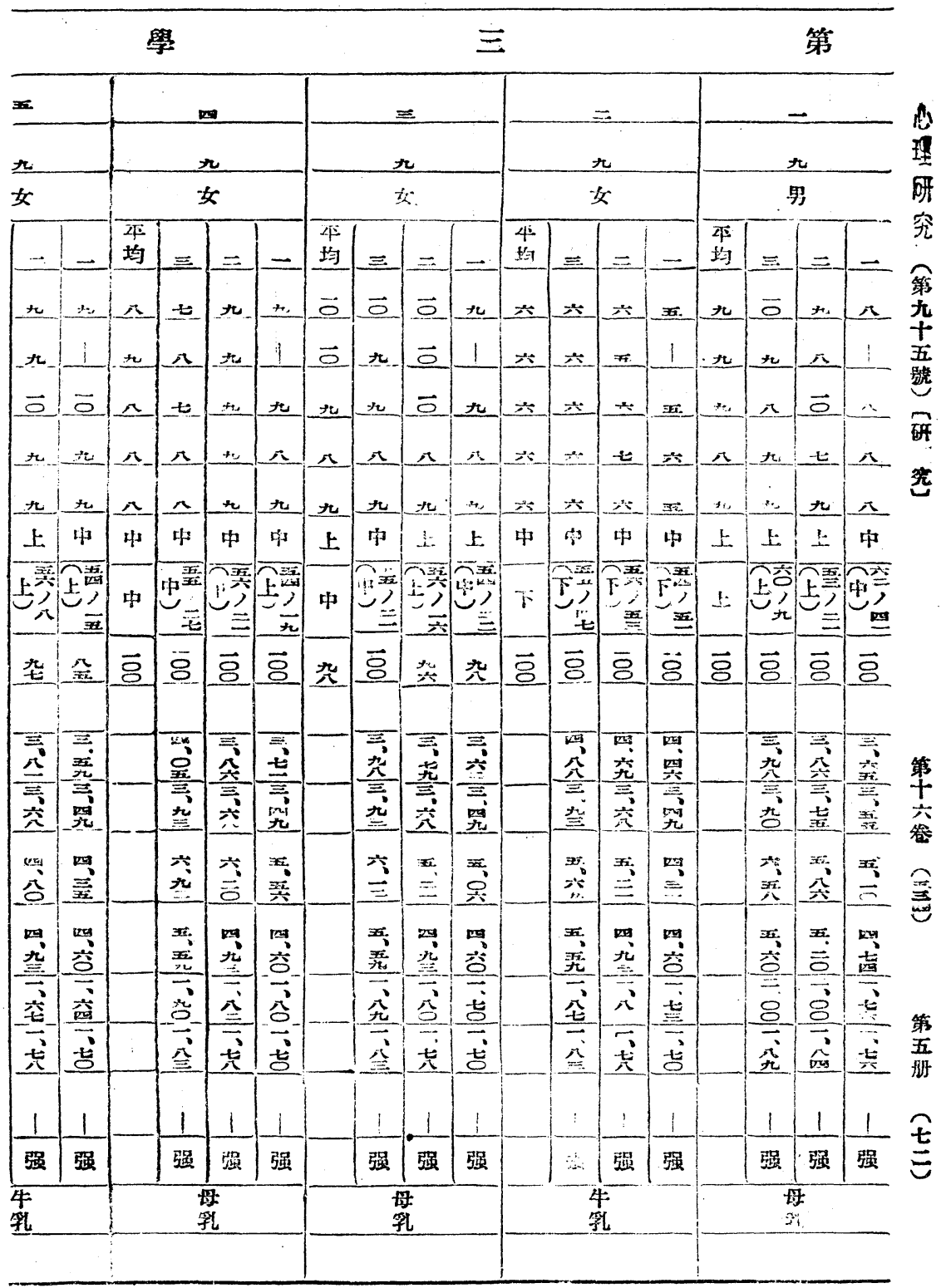




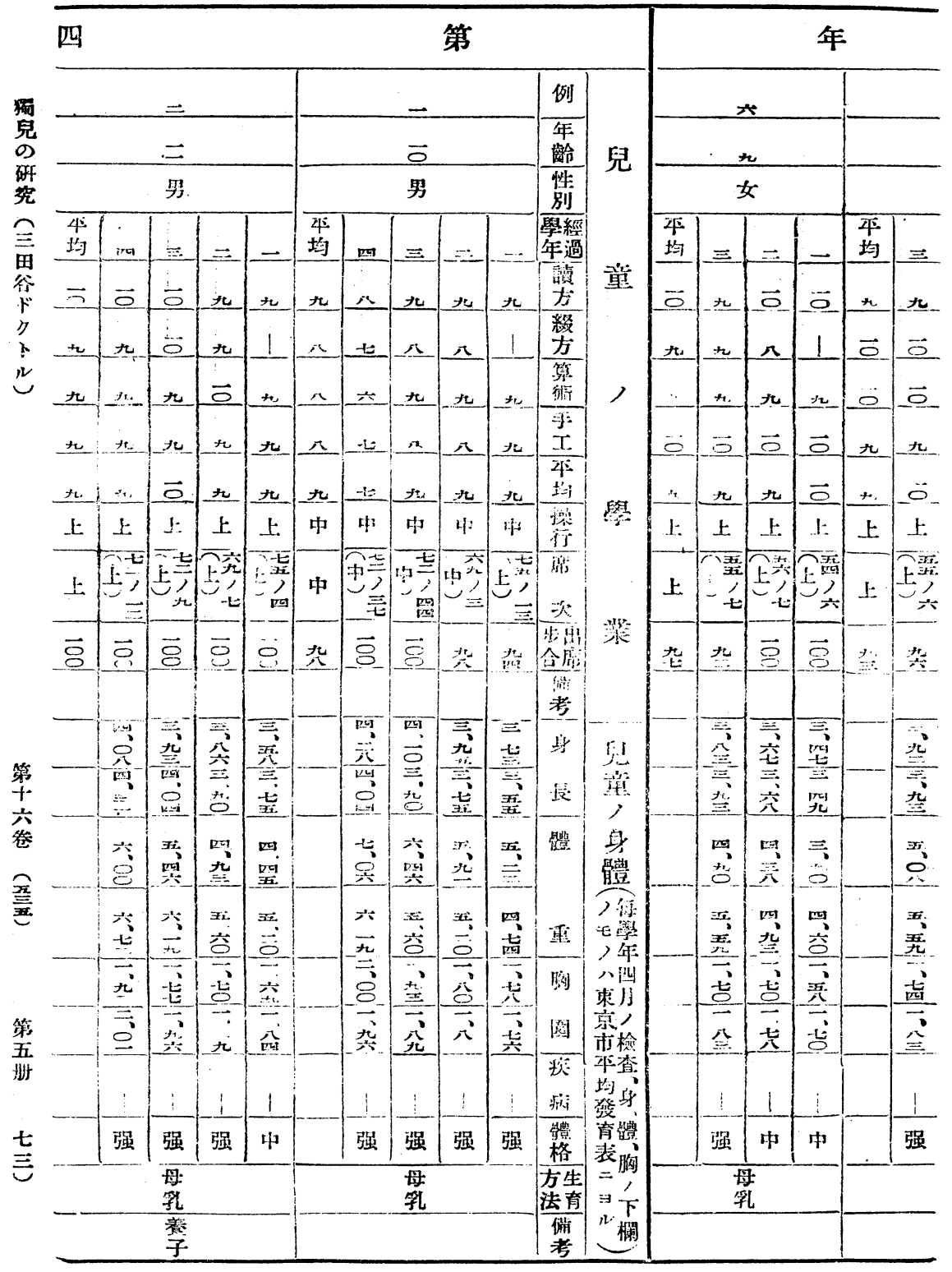




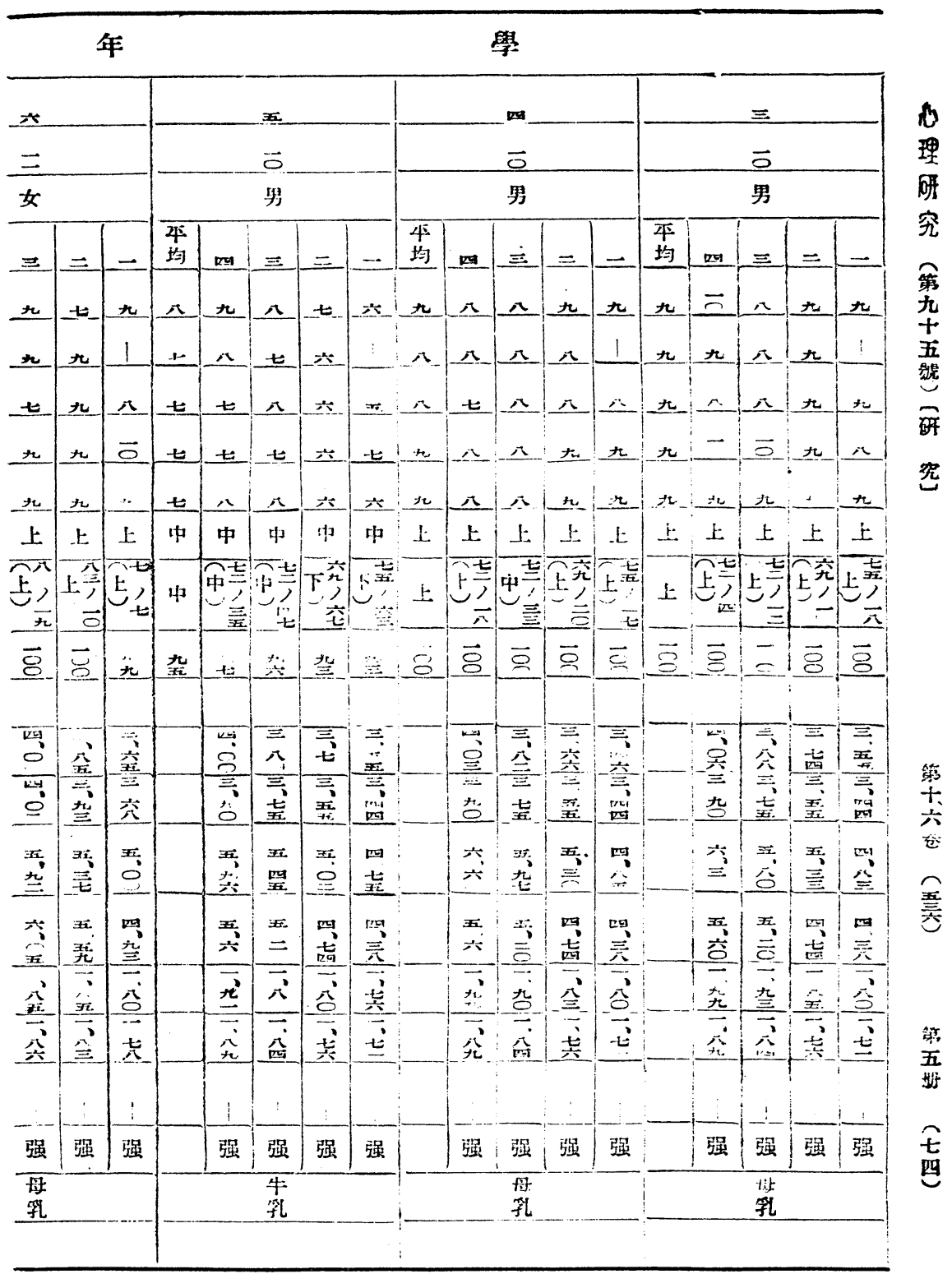




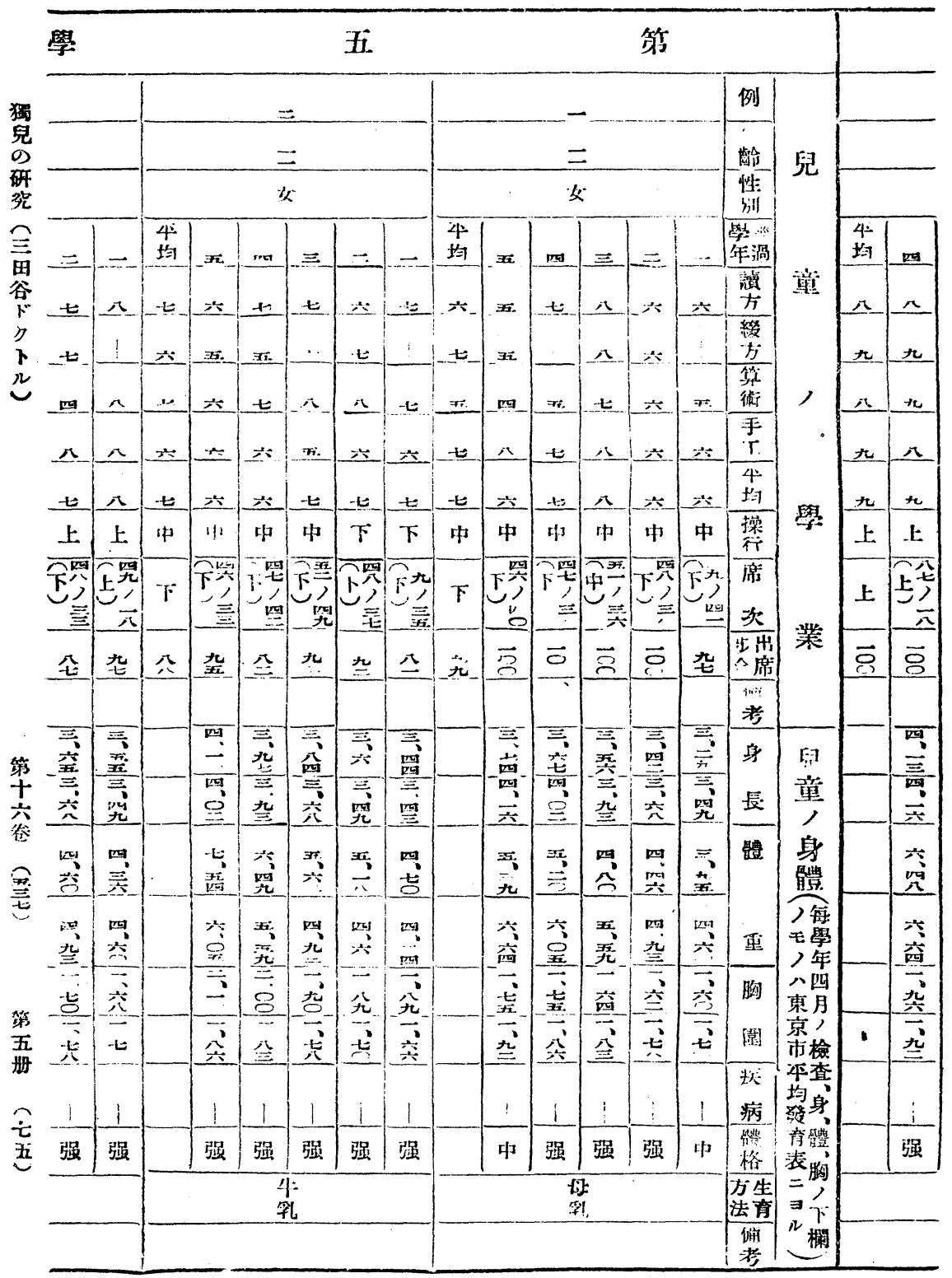




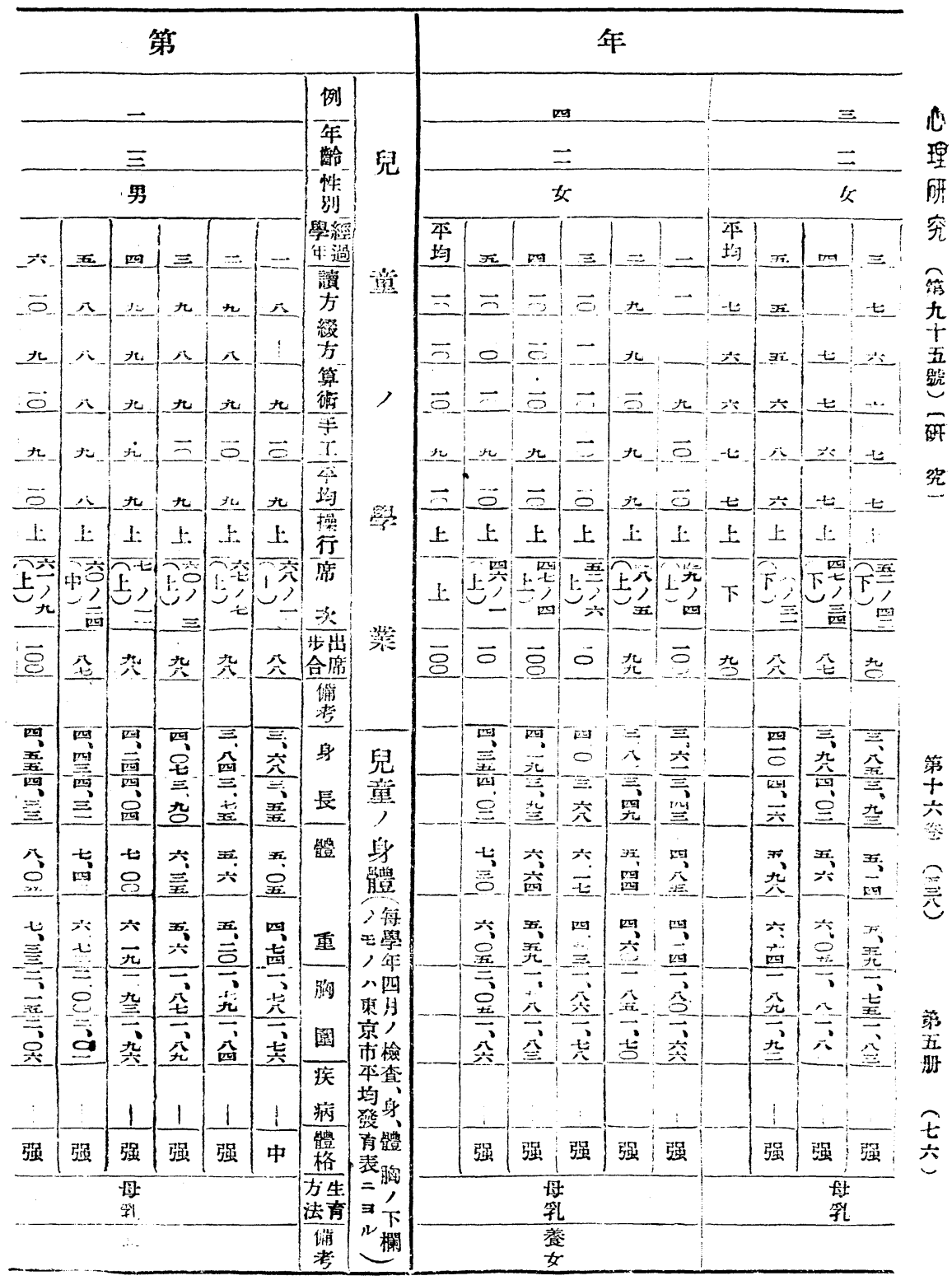




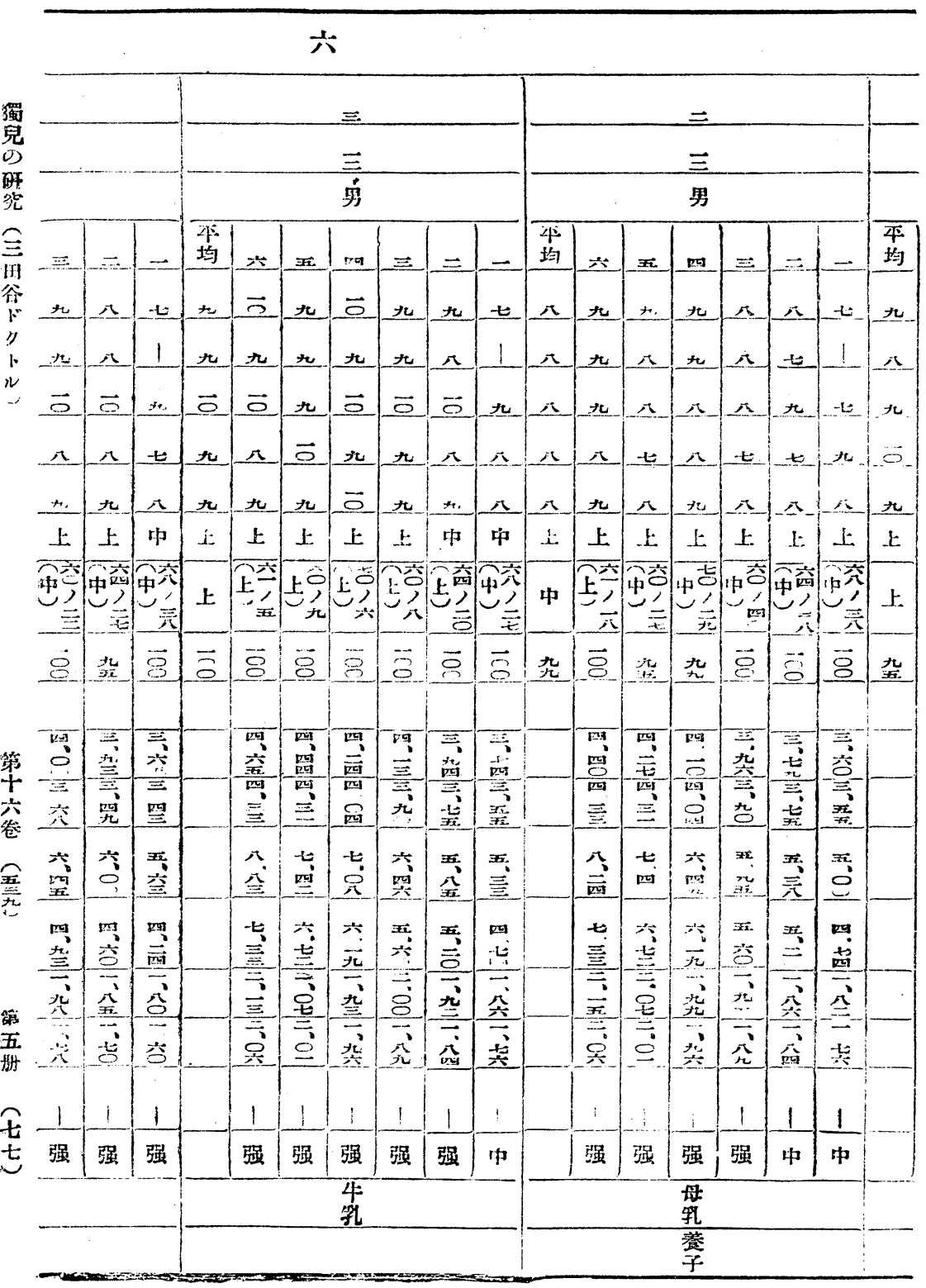




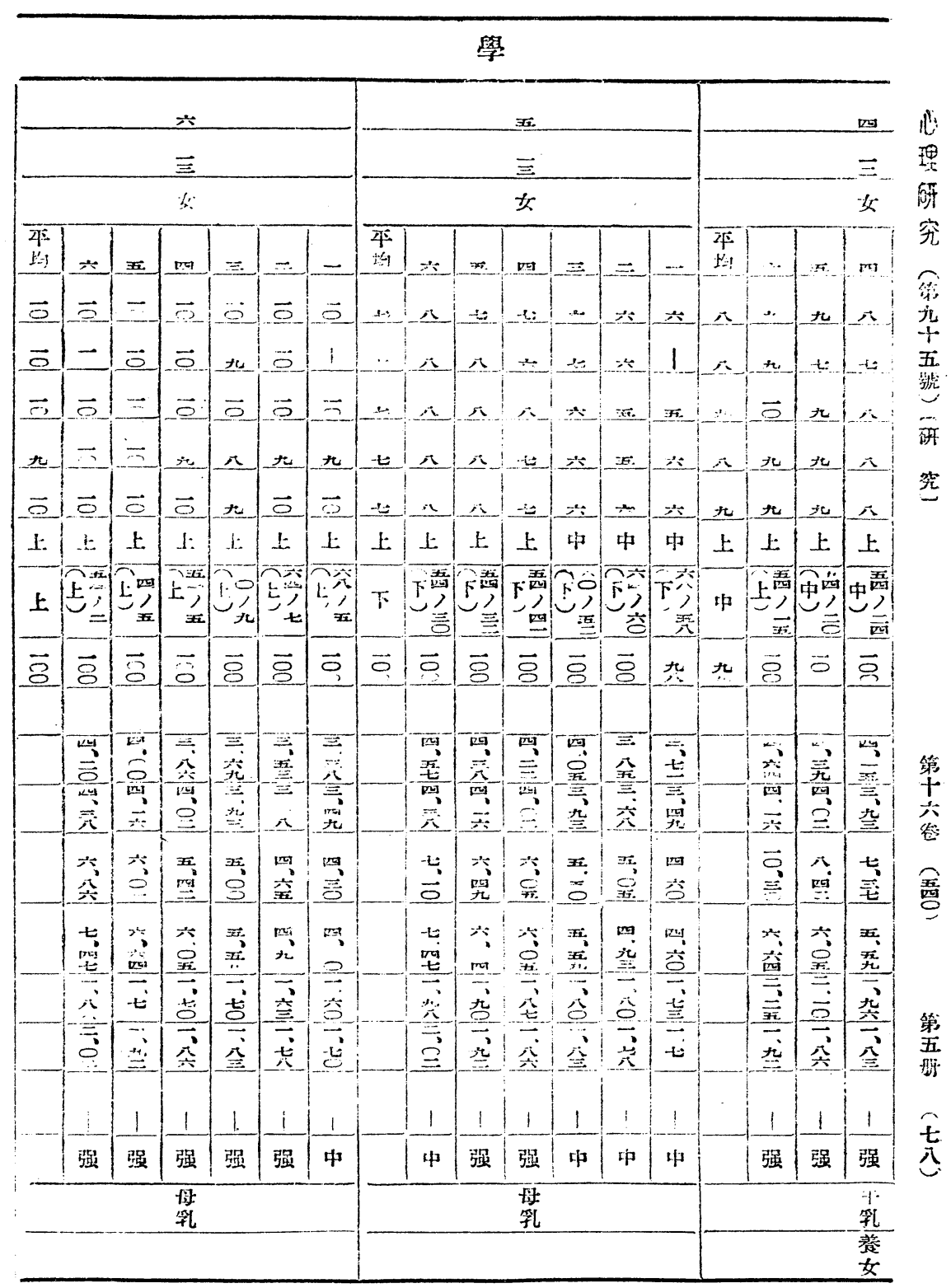



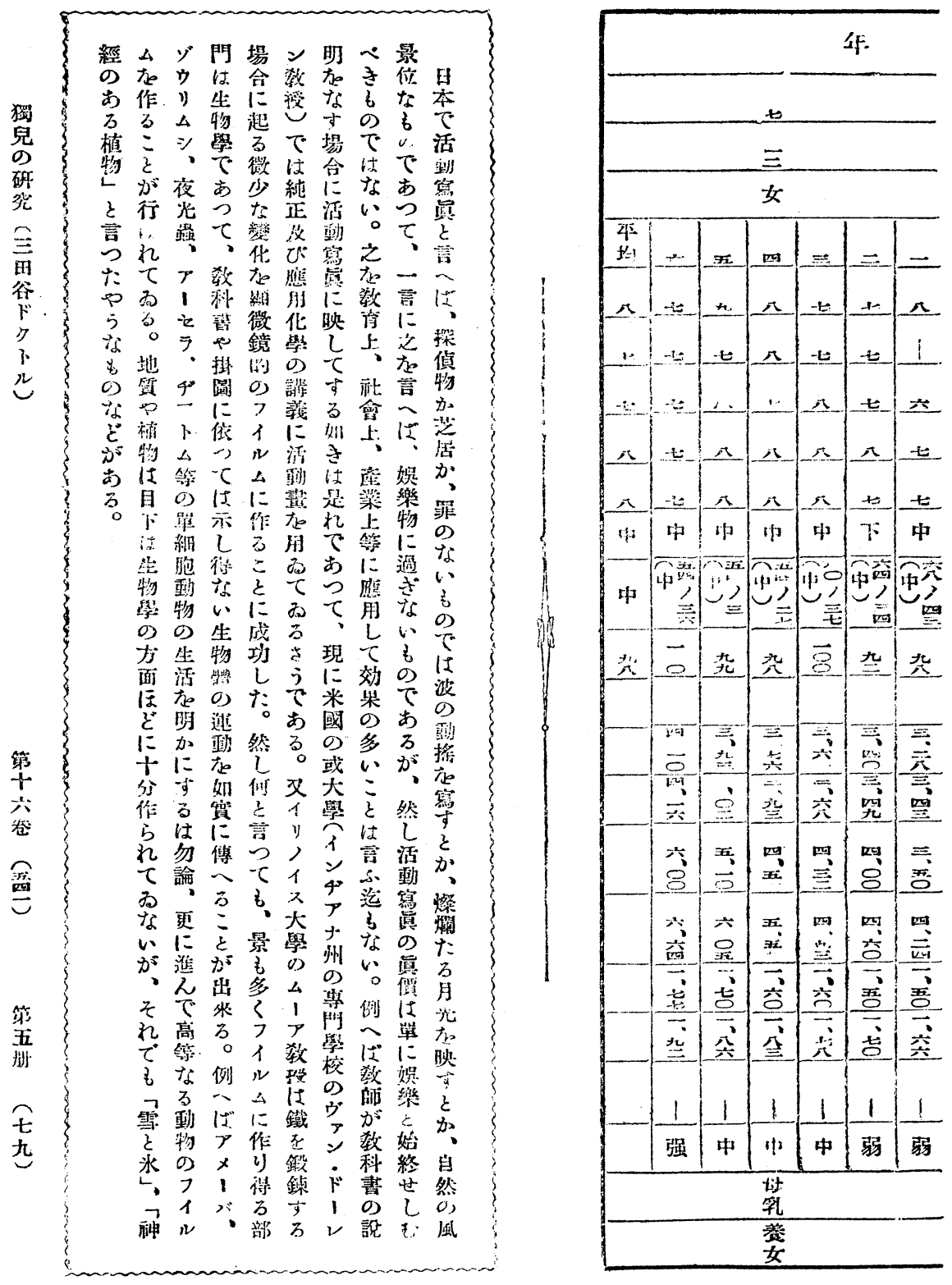